\title{
KAHRAMANLARININ ÖZELLIKLERİ BAKIMINDAN BİR DESTAN ANLATIMININ İNCELENMESİ: HAKAS DESTANI ALTIN ÇÜS
}

\author{
Yaprak Pelin ULUIŞIK
}

ÖZ: Güney Sibirya Türk topluluklarından biri olan Hakasların “alıptığ nımah” adını verdikleri, tam tarihleri bilinmese de diğer destan örneklerinden daha da eski zamanlara dayandırılabilen ve birden çok tarihî tabakayı bünyesinde barındırdığı tespit edilebilen destan örnekleri mevcuttur. Manzum oluşu, müzik eşliğinde haycılar (destan anlatıcıları) tarafından söylenişi ve söylenişindeki kalıp ifadeler, tasvirler, tekrarlar, uyak ve redif kullanımı vb. ile tipik bir Hakas destanı olan Altın Çüs destanı, mitolojik altyapısı ve Şamanizm unsurları ile de Hakasların alıptığ nımahlarına örnek olarak gösterilmektedir. Kahramanın özelliklerinin ön plana çıkmaya başladığı, yeraltı mücadelelerinin yeraltının yeryüzündeki temsilcileri ile yeryüzünde yapılmaya başlandığı bu destanda üç ana kahraman mevcuttur: Altın Çüs, Alıp Möke ve Üzüm Han. Hakas destanları üzerine yapılan çalışmalar, destanların icrası sırasında üç kuşak anlatımının gelenek olduğunu göstermektedir. Altın Çüs destanı da Alıp Han'ın anlatımı ile başlayıp Altın Çüs'e, oradan Altın Çüs'ün yoldaşı Alıp Möke'ye ve oradan da Alıp Möke'nin oğlu Üzüm Han'a geçer. Destanda bu üç kahraman aynı anda hayattadır ve destan boyunca kahramanların üçü beraber anlatılır.

Bu makale, destan kahramanlarının doğumu, adlarının verilmesi, fiziksel özellikleri; atları, savaş giyimleri ve silahları; verdikleri mücadeleler ve savaşları; onlara yardımcı ve onların karşısında olan destan kadrosu; sihir (büyü) yapma, şekil değiştirme, ölüyü diriltme ve emçilik, bilici ve sezici olma vb. olağanüstülükleri açısından Altın Çüs destanının bir incelemesi şeklindedir. İnceleme sırasında destan anlatımındaki konu sıralamasına önem verilmiş, kahramanların özellikleri ile ilgili açıklamalar bu sıralamaya göre yapılmıştır. Kahramanların özelliklerinden söz edilirken Altın Çüs destanının nazım parçalarından da örnekler verilmiştir.

Anahtar Kelimeler: Hakas, Altın Çüs, destan, kahraman, mitoloji.

\section{AN ANALYSIS OF AN EPIC TELLING IN TERMS OF HERO CHARACTERISTICS: KHAKASSIAN EPIC “ALTIN ÇÜS”}

ABSTRACT: One of the Southern Siberian Turkish communities, the Khakas have epic examples which they called "alıptig nımah" the true date of which are not known but dating back earlier dates than other epics and bearing more than one historical layers. Being a Khakas epic with its poetic structure, told by haycis (epic tellers) in accompany with music, usage of cliché

\footnotetext{
* Öğr. Gör. Dr., Gazi Üniversitesi, Türk Dili Bölümü, ypeline@ hotmail.com ORCID: https://orcid.org/0000-0002-1757-0320
}

Geliş Tarihi (Received): 18.11.2018

Kabul Tarihi (Accepted): 14.11.2019

Yayın Tarihi / Published: 17.02.2020 
expressions, depictions, repetitions, rhymes and repeated words, Altın Çüs Epic is given as an example of Khakas alıptig nımahs with its mythological structure and Shaman components. There are three main heroes in this epic where the features of these heroes are in the forefront, underground fights are made on the surface with the representatives of underground on the surface: Altın Çüs, Alıp Möke and Üzüm Khan. The studies carried out into Khakas epics show that three generation telling is a tradition during the fulfilment of epics. Therefore, the epic of Altın Çüs starts with the telling of Alıp Khan, passes to Altın Çüs and then to Alıp Möke, the comrade of Alıp Möke, and finally to Üzüm Khan, the son of Alıp Möke. The three heroes in the epic are alive at the same time and all the three are told together throughout the epic.

The current article is an investigation into the epic of Altın Çüs in terms of the birth of the epic heroes, name giving, physical characteristics, their horses, war clothing and weapons, the struggles they made and their wars, the cast of epic helping and opposing them, miraculousness such as magic making, change of shape, reviving the death, pharmacy, being a scientist and prophecy etc. In the investigation, the order of topics was given importance in telling the epic, the explanations with regard to the characteristics of the heroes were made depending on this order. While talking about the characteristics of the heroes, example were given from the poetic parts of Altın Çüs epic.

Keywords: Khakas, Altın Çüs, epic, hero, mythology.

Giriş: Güney Sibirya Türkleri, sözlü kültür ögelerinin zenginliği ve özgünlüğü ile dikkati çeken Türk topluluklarındandır. Onların sahip oldukları inanç sistemlerinden ve yerleştikleri coğrafyadan fazla uzaklaşmamaları, bu kültürel ögelerin en eski hâllerini aşağı yukarı koruyabilmelerini ve bu ögeleri gelenek içerisinde devam ettirebilmelerini sağlamıştır. ${ }^{1}$ Güney Sibirya Türkleri arasında yer alan Hakas Türkleri de, mitolojik temelli ve Şamanizm unsurları ağır basan, tam tarihleri belli olmadığı hâlde bu iki özelliğinden dolayı oldukça eski dönemlere ait oldukları söylenebilen birçok kahramanlık destanına sahiptir. Kahramanlar için çoğunlukla "alıp" kelimesi tercih edildiğinden bu kelime, tür adına da yansımış ve bu destanlara "alıptığ nımah" adı verilmiştir. ${ }^{2}$ Alıptığ nımahlar, anlatıldıkları coğrafya, geçtikleri dönem; destan anlatımında belirtilen halk ve o halkın içinde bulunduğu siyasi, ekonomik, askerî, dinî, sosyal, kültürel vb. koşullar hakkında en eski bilgilere sahip olan anlatılardır. Bu destanlar, sadece oluştukları dönemin özelliklerini değil, anlatı geleneği içerisinde, icra sırasında kaybettikleri ve kazandıklarıyla birden fazla tarihî tabakayı da bünyelerinde barındırır. Bu konu ile ilgili olarak Erhan Aktaş şunları söylemiştir: "Destanlarda mevcut tarihi tabakalar yalnızca savaş, istila, göç vb. konular çerçevesinde değil toplumun dini ${ }^{1}$ Sözlü ürünlerin yazıya geçirilmesinde geç kalınması, yazıya geçirilenlerin üzerinde yapılan
çalışmaların sayıca az ve içerik olarak yetersiz olması, birçoklarının yazıya geçirilmesine
rağmen hâlen incelenmemesi gibi nedenlerden dolayı bu ürünler hak ettikleri değeri tam olarak
görememiştir ve sözlü anlatı geleneği de zaman içerisinde maalesef yok olmuş̧tur.
${ }^{2}$ Erhan Aktaş, "Aile İçi İlişkiler Çerçevesinde Hakas Destan Kahramanları", Türk Külttürü,
2016/2, 2016, s. 47-58.
Trakya Üniversitesi Edebiyat Fakülttesi Dergisi, 
inançları ve bunlara bağlı pratiklerin yer alması, yer ve kahraman isimleri, halk algısı vb. konularla da takip edilmektedir. Bizim incelediğimiz destanlar arasında tarihi ve buna bağlı gelișen unsurlar bakımından tek tabakalı destan bulunmaz. Bunun en büyük sebebi elimizdeki hiçbir sözlü edebi yaratmanın urtext halinde yani ilk yaratıldığı günkü halinde olmamasıdır. Her bir icra bu eserlerin yeniden yaratılmasıdır." 3

Gülsüm Killi Yılmaz, "Hakaslarda Destanc1lık Geleneği II: Biçim, İçerik, İcra” adlı makalesinde, M. A. Ungvitskaya'nın en eski Hakas destanlarını MÖ 7. yüzyıla kadar dayandırılabileceği hakkındaki görüşünü aktarmıştır. Ungvitskaya, Hakas Türklerinin destanları için en eski Hakas dönemine (MÖ 7-MS 5. yy.) ait olan ilk şekillerden bahsederek bu tarz destanların mitolojik yönlerinin ağır bastığını, bu destanlarda olağanüstü varlıkların sayıca çok olduğunu, yeraltına inişlerin ve yeraltı mücadelelerinin sıkça anlatıldığını belirtir. Bir de eski Hakas dönemine (MS 6-13. yy.) ait olan destanlar mevcuttur ki Ungvitskaya alıptığ nımahları, bu döneme ait destan anlatıları olarak kabul eder. Bahsedilen dönemde kahramanın özellikleri ön plana çıkmaya başlamıştır, kahraman sürekli halkı ve malı için savaş vermektedir ${ }^{4}$, yeraltı ile olan mücadeleler ise yerini, yeraltının yeryüzündeki temsilcileri ile olan mücadelelere bırakmıştır. ${ }^{5}$ Ungvitskaya'nın en eski Hakas ve eski Hakas dönemi şeklinde Hakas destanlarını dönemlere ayırma fikri, Özkul Çobanoğlu'nun "Türk Dünyası Epik Destan Geleneği” adlı eserinde Türk kahramanlık destanları için yaptığı tasnifi hatırlatmaktadır. Çobanoğlu da bu tasnifinde Ungvitskaya ile benzer kriterleri göz önünde bulundurarak Türk epik destan geleneğinin verimlerini eski ve yeni destanlar şeklinde ikiye ayırır. Yeni destanlar da arkaik destanlar, kahramanlık destanları ve tarihi destanlar olmak üzere üçe ayrılır. ${ }^{6}$ Çobanoğlu, Hakas destanlarının bir kısmını arkaik destanlar içerisinde vermiştir. Mehmet Aça, sözlü gelenekteki tür ve şekil adlandırması ile ilgili görüşlerini belirttiği bir çalışmasında, Türklerin dünya görüşü ile çoğunlukla mitolojik bir karaktere sahip olan alpların olağanüstü göksel güçlere, vahşi hayvanlara, ülkelerini işgal edip halklarını esir eden dış düşmanlara ve kendi halklarına zulmeden hanlara karşı yürüttükleri mücadeleyi hikâye eden, kahramanlık içerikli olağanüstü-fantastik anlatmaların adlandırılmasında kozmogonik destan, mitolojik destan,

\footnotetext{
3 Erhan Aktaş, "Hakas Destan Kahramanları Üzerine Bazı Değerlendirmeler", Çağdaş Türkoloji Araştırmaları, Ank. Ünv. Basımevi, Ankara-Abakan, 2014, s. 208.

${ }^{4}$ Kahraman-halk ilişskisi için E. Aktaş, agm., s. 198.

${ }^{5}$ Gülsüm Killi Yılmaz, "Hakaslarda Destancılık Geleneği II: Biçim, İçerik, İcra”, Modern Türklük Araştırmaları Dergisi, 7/3, 2010, s. 156-157.

${ }^{6}$ Özkul Çobanoğlu, Türk Dünyası Epik Destan Geleneği, Akçă̆ Yayınları, Ankara, 2003, s. 49-55. 
Şamanizm kökenli destan, eski destan ${ }^{7}$; köne epos, arkaik epos, batırlık ertegi vb. adların kullanıldığını; Altay, Hakas ve Tuva gibi Türk topluluklarının bu tarz anlatıları için "köne epos"un kullanılmasının tercih edilmesi gerektiğini söyler. Aça'ya göre köne eposlar, mitten klasik destana geçiş aşamasını oluşturmaktadır ve mit, efsane, masal gibi türlerin özelliklerini de barındırmaktadır. Bu özellikler zaman içerisinde destan metninden atılmıştır ve bu destanlar, tarihî-realist destanlara dönüşmüştür. ${ }^{8} \mathrm{Bu}$ bilgilere dayanarak

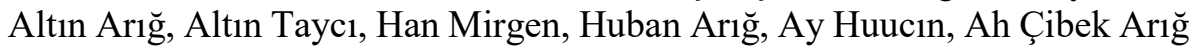
vb. Hakas destanlarının, Ungvitskaya'nın tasnifine göre eski Hakas dönemi destanları, Özkul Çobanoğlu'nun tasnifine göre arkaik destanlar ve Mehmet Aça'ya göre de köne eposlar sınıfına girdiklerini söylemek mümkündür.

Altın Çüs destanı da Hakas Türklerinin, ana kahramanı erkek olan alıptı̆̆ nımahları / köne eposları / arkaik destanları ${ }^{9}$ arasında yer almaktadır.

${ }^{7} \mathrm{Bu}$ destan adlandırmalarının ayrıntıları için bk. Emine Gürsoy Naskali, "Destanın Tarifi”, Türk Dili Araştırmaları Yıllığı-Belleten 1992, Ank. Ünv. Basımevi, Ankara, 1995, s. 1-8.

8 Mehmet Aça, “'Köne Epos’ (Arkaik Destanı) Kavramı ve Türk Halk Hikâyelerindeki ‘Âşıklara Mahsus Evlilik' Konusunun Kaynaklarından 'Alplara Mahsus Evlilik'”, Millî Folklor, 12/47, 2000, s. 13-14.

9 Burada ek olarak şunu belirtmek gerekir ki, diğer Türk destanlarına oranla Hakasların destanlarında ana kahramanı kadın olan destanların sayısı dikkat çekici bir şekilde fazladır. Bunun sebebini anaerkil dönemde söylenen eski destanlar olmalarına, Şamanizmin etkisi ile kadın şamanların önemli olduğu dönemlerde anlatılmaya başlanmalarına vb.ye bağlayan araştırmacılar mevcuttur. Bu destanlara Huban Arı̆ , Ah Çibek Arı $\breve{g}$, Altın Arı̆ ve Ay Huucın gibi destanlar örnek olarak verilebilir. Bu tip destanlarda, diğer destanlarda erkek kahramanların sahip oldukları tüm özelliklerin kadın kahramanlarda da mevcut olduğu görülür. Olağanüstü fiziksel yapının, savaş̧̧ılığın, liderliğin, dünya nizamını sağlama amacının yanı sıra Hakas destanlarındaki mitolojik altyapı ve Şamanizm etkisi ile bilicilik ve sezicilik, büyü (sihir) yapma, emçilik, hava olaylarına müdahale etme, olağanüstü varlıklardan yardım alma, sihirli nesnelere sahip olma, yeraltına inme, şekil değiştirme vb. özellikler de kadın kahramanın bünyesinde verilmiştir. Hakas Türklerine ait kadın ve erkek kahramanlı destanlar arasında en belirgin fark, kadın kahramanlı destanlarda ana kahramanın hiçbir zaman evlenmemesidir. $\mathrm{O}$ kendisini ailesine, yakınlarına ve halkına adamıştır. Evlenmeyi düşünmez, evlilik fikri ve lafı onu kızdırır; hatta evlenmek için kendisine talip olan yiğitleri öldürür. Bazı destanlarda bu kadın kahramanların kaderlerinde başından beri evlenmek yazılı olmadı $\breve{g}$, destan anlatımı sırasında doğrudan söylenir (Hakasların kız alp yiğitlik destanlarında destan kahramanının evlenmemesi ve kendisi ile evlenmek isteyen taliplerini öldürmesi konusunda bk. Timur Davletov, Ah Çibek

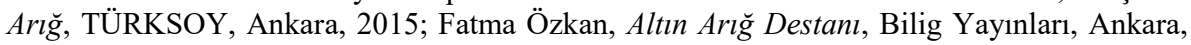
1997). Erkek kahramanlı destanlarda ise kahraman, zamanı geldiğinde kendi bulduğu, kutsal sudurda (bitikte) yazan, ailesinin almasını söylediği, dost / düşman hanların akrabalarından olan vb. kadınlarla evlenir. Altın Çüs destanında evlilik ile ilgili iki dikkat çekici durum söz konusudur: 1. Altın Çüs, destan sahnesine çıktığında hâlihazırda Ah Çibek Arı̆̆ ile evlidir. 2. Alıp Möke, Hıyan Arığ ile evli olduğu hâlde, oğlu Üzüm Han'ın isteği üzerine düşman Alıp Han Hıs ile ikinci evliliğini yapar. Bu ikinci durum için "Aile İçi İlişkiler Çerçevesinde Hakas Destan Kahramanları" adlı makalesinde Aktaş şu bilgileri vermiştir: "Geleneksel Türk ve Hakas aile kurumunda ekseriyetle tek eşlilik yani monogami ve bireyin eşini bağlı bulunduğu 
Destanın, diğer Hakas destanları gibi mitolojik bir altyapısı ve Şamanizm'e ait unsurları söz konusu olmakla beraber bu destan manzum oluşu, müzik eşliğinde haycılar tarafından söylenişi ve söylenişsindeki kalıp ifadeleri, tasvirleri, tekrarları, uyak ve redif kullanımı vb. ile de tipik bir Hakas destanıdır. Bu makalede incelediğimiz Altın Çüs destanı, Hakas Türklerinin ünlü haycısı (destan anlatıcısı) Semyon Prokopyeviç Kadışev'den derlenmiştir. 1951'de “Alıptı̆̆ Nımahtar" (Kahramanlık Destanları) adı ile yayımlanan kitapta "Ah Oy Attığ Alıp Han" (Ak Kula Atlı Alıp Han) başlığı ile yer almaktadır. Ardından T. G. Taçeyeva tarafından, on bir bölüme ayrılmış ve "Altın Çüs" adı ile yayımlanan "Altın Arı̆̆ Alıptı̆̆ Nımahtar" kitabında yeniden bu destana yer verilmiştir. ${ }^{10}$

\section{Altın Çüs Destanı ve Destan Anlatımı Sırasında Kahramanların Özelliklerinin Verilişi}

Özelde Hakas, genelde Güney Sibirya Türk destanları, diğer Türk destan örneklerinden daha ayrımlı ve orijinal başlangıç kalıpları ile oluşturulmuştur. Hakas destanlarının, yaratılış mitlerini çağrıştıran ifadeler ile başladıkları dikkati çeker." Örneğin Huban Arı̆̆, "Yer ilk kez damarlar saldığında, / Köklerini salıp ağaçlar büyüdüğünde, / Demir ilk kez işlendiğinde, / Bütün yer üstü güzel yaratıldığında, / ..."12 satırları ile; Han Mirgen destanı dünyanın daha yeni yaratıldığı, bakırın yeni kaynayıp döküldüğü, nehirlerin, denizlerin ve okyanusların ilk kez aktığı, yemyeşil ağaçların büyük rüzgarın etkisiyle özgürce sallanmaya başladığı, dört ayaklı hayvanların koşmaya, çatal kanatlı kuşların uçmaya, insanların burunlarıyla nefes almaya başladığ $1^{13}$ ifadeleri ile; Ah Çibek Arığ destanı "Yer ilk kez oluşmuştur, / Bakır ${ }^{14}$ ve demirler ilk kez

sosyal yapının dışından seçmesi olan egzogami esas olmakla birlikte Eski Türklerdeki yaklaşımda üst sınıfın evliliklerinde çok eşlilik yani bir erkeğin birden fazla kadınla evlenmesi olan polijini (çok karılı1ık) görülebilmektedir.” (Erhan Aktaş, "Aile İçi İlişkiler Çerçevesinde Hakas Destan Kahramanları”, Türk Kültürü, 2016/2, 2016, s. 47-58; Mehmet Ali Yolcu, Türk Kültüründe Evliliğe Bă̆lı Kaçınmalar, Kömen Yayınları, Konya, 2014, s. 154, 181)

${ }^{10}$ Erdal Şahin, Hakas Destanı Altın Çüs, Türk Dünyası Araştırmaları Vakfı, İstanbul, 2007, s. 20.

${ }^{11}$ Erhan Aktaş, "Hakas Türk Destanlarında Başlangıç ve Bitiş Kalıpları”, Prof. Dr. Fikret Türkmen Kitabı, Ege Ünv. Türk Dünyası Araştırmaları Enstitüsü, İzmir, 2012, s. 650.

12 Timur Davletov, Huban Arığ. Hakas Türklerinin Kadın Yiğitlik Destanı, TÜRKSOY Yayınlar1, Ankara, 2006, s. 1.

${ }^{13}$ Timur Davletov, Hakas Kartalı Han Mirgen, Yurt Kitap-Yayın, Ankara 2005, s. 5.

14 Timur Davletov, tamamında olmasa da bazı bölümlerinde geçen motifler ve özellikle destanın bakır ile ilgili bölümü dolayısıyla Ah Çibek Arığ destanının, adını Hakas topraklarındaki Afansayev Dağı'ndan alan Afanasyevo kültürü dönemine ait olduğunu, yani yaklaşık 6750 - 7000 yıllık bir geçmişe sahip olduğunu ifade etmiştir (Timur Davletov, "Türk Halklarının Köroğlu ve Ah Çibek Arığ Destanlarında Kadının Toplumsal Yeri”, Türk Tarihinde İz Bırakan Bolulular Çalıştayı Bildiriler, Kaan Matbaa, İstanbul, 2015, s. 219-220; Timur Trakya Üniversitesi Edebiyat Fakültesi Dergisi, Cilt: 10 Sayl: 19, Ocak 2020, s. 169-192 
katılaşmıştır, / Dünyanın en yükseği ak tashıllar (dağ dorukları) / Büyümüş durmaktadır." 15 ve Altın Arı̆̆ destanı "Yeryüzü oluşmaktadır. / Madenler ortaya çıkmaktadır, / Yerin yükseği ak zirveler, / Oluşmaktadır." ${ }^{16}$ dizeleri ile; Altın Taycı destanı "Bakırla karışarak toprağın oluştuğu, / Otların köklerini salıp büyüdüğü, / Sert ağaçların, sık orman olup, / Yeryüzünü bezediği zamand1." ${ }^{17}$ misraları ile; Ay Huucın destanı ise yerin ilk kez yaratılmasından hemen sonra kızıl bakırların bulunur zamanı olduğunun belirtilmesi ile ${ }^{18}$ başlamaktadır. Hakas destanları bu benzer cümlelerden sonra ak dağlardan akan ak sulardan, irmaklardan ve göllerden bahsedilerek devam eder. Altın Çüs destanının başlangıcındaki ifadeler de Ah Çibek Arı̆̆ ve Altın Arı̆̆ destanlarındaki başlangıç ifadelerine birebir benzer. Önce yerin yaratıldığı, bakırın meydana geldiği ve yerin zirvesi ak dağların yükseldiği söylendikten hemen sonra ak dağlardan akan ak ırmağın aşağısında ve yukarısında sayısız halkın yaşadığı ve buraların hanının dokuz kulaç boylu, aran çula (yüğrük) ak kula atlı Alıp Han olduğu anlatılarak destana başlanmıştır. Destanlarda genellikle yaratılıştan, destan kahramanının asıl yurdundan ve ailesinden bahsedildikten sonra kahramanının olağanüstü doğumuna geçilir. Bu hızlı geçişin ve kahraman hakkındaki olağanüstülüğün veriliş sebebi, dinleyicinin ilgisini en baştan kahramana çekmek ve destanda canlılığı (hareketliliği) yakalamaktır. Kahramanının olağanüstü doğumu kısmında en çok kullanılan motif "çocuksuzluk"tur. Uzun süredir çocuk sahibi olamamış bir çift olan kahramanın ebeveyni, sonunda -geç de olsa- dua etme, tavsiye edilen pratikleri veya ritüelleri uygulama veya ebeveynden birinin bir imtihanı geçmesi yoluyla çocuk sahibi olur. Naciye Yıldız, "Türk Destanlarında Çocuksuzluk" adlı makalesinde kahramanların olağanüstü doğumları üzerinde durmuş ve Kazak, Kırgız, Türkmen, Özbek, Altay, Hakas, Tuva, Şor, Karaçay-Malkar, Karakalpak, Başkurt, Tatar, Gagavuz, Kırım ve Uygur destanlarında çocuksuzluk hakkında örnekler vermiştir. Hakas destanlarından

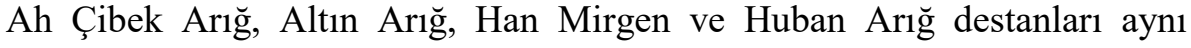
çocuksuzluk motifine yer verir. Altın Çüs destanında da Alıp Han ve eşi Altın Arığ, ihtiyarlamış ama çocuk sahibi olamamış bir çifttir. Altın Arı̆̆ geç yaşında hamile kalır; doğacak çocuk bir erkek olacaktır. Türk destanlarında "geç yaşta çocuk sahibi olan anne" özelliğinin yanı sıra destan

Davletov, "Türk Halklarının Dede Korkut Kitabı ve Ah Çibek Arığ Destanında Kadının Toplumsal Yeri”, III. Uluslararası Türk Dünyası Kültür Kongresi: Dede Korkut ve Türk Dünyası, Ege Üniversitesi Türk Dünyası Araştırma Enstitüsü, İzmir, 2016, s. 1663-1664).

15 Timur Davletov, Ah Çibek Arı ğ, TÜRKSOY Yayınları, Ankara, 2015, s. 43.

${ }^{16}$ Fatma Özkan, Altın Arlğ Destanı, Bilig Yayınları, Ankara, 1997, s. 35.

${ }^{17}$ Mehmet Kara, Hakas Destanı Altın Taycı, Harf Yayınları, Ankara, 2013, s. 15.

${ }^{18}$ Pervin Ergun, Hakas Destancılık Geleneği ve Ay Huucın, Kömen Yayınları, Konya, 2010, s. 181. 
kahramanlarının eşlerinde görülen "bilici ve sezici kadın” özelliğine Altın Arı '̆’’n sahip olması ile de bu destan, diğer destanlarla benzerlik gösterir. ${ }^{19}$ Alıp Han'ın yurduna ilk saldırılacağı gece Altın Arığ bir türlü uyuyamaz; bir terslik olacağının farkındadır. Yurda, Alıp Hara Han adlı düşman saldırır. Alıp Han, eşi Altın Arığ'a, eğer bu saldırı karşısında verdiği mücadele sırasında kendisine bir şey olursa doğacak olan çocuğu ak kula ata verip ${ }^{20}$ onu serbest

${ }^{19}$ Hakas destanlarında kadın kahramanların rolü, diğer bölgelerin destanlarına nazaran baskın olduğundan ana kahramanları erkek olan destanlarda dahi kadın kahraman kadrosunun sayıca fazla ve nitelik yönünden dolu olduğu görülür. Altın Çüs destanında da ana kahramanlar erkektir; fakat kadın kahraman kadrosu da azımsanamayacak kadar özellikli kişilerden oluşmaktadır. İlk olarak bilici ve sezici Altın Arı̆̆'dan bahsedilebilir. Alıp Han'ın eşi, Alıp Möke'nin annesi olan Altın Arığ, doğum yaptıktan hemen sonra çocuk doğurduğunu inkâr ettiği için düşman Alıp Hartığa tarafindan öldürülür ve daha sonra destan kahramanı Altın Çüs tarafından diriltilir. Destan sahnesine ikinci olarak çıkan kadın, düşman Çil Hara Hıs'tır. Dokuz kulaç boylu kara kula atlı Alıp Hara Han'ın kızı, kara doru atlı Alıp Hartığa'nın kız kardeşidir. "At götürmez" lakaplıdır. Destanda üçüncü kadın, yine bir düşmandır. Altmış saç örgüsü arkasına, elli saç örgüsü omzuna dökülen; geniş omuzlu, kabarı göğüslü; dokuz düğmeli ak deri zırh giymiş, ay genişliğinde kılıçlı, ok ve yay kullanmak konusunda usta, dokuz kulaç boylu yüce boz atlı kız yiğit olarak destanda tasvir edilen bu kız, Alıp Han Hıs'tır. Destanın sonunda bu düşman kız, Alıp Möke ile evlenir. Alıp Han Hıs'tan sonra destanda kara derili, büyük kulaklı yılan şeklinde ortaya çıkan ama esas şekli bu olmayan Huu İney Ana'dan söz edilir. Şekil değiştirme özelliğine sahip bu kara büyücü, muhtemelen Alıp Hara Han ve oğlu Alıp Hartığa'nın emrinde bir varlıktır. Alıp Hara Han'ın yerini, suyunu o tutar (korur). Kendisinden bahsedilirken deri kulaklı, biz burunlu ve bileği taşı karınlı şeklinde dış görünüş özellikleri belirtilir. Destanda adı geçen bir başka kadın, Çarıh Tana'dır. Çaas Han'ın eşi olan Çarıh Tana bilici, sezici ve emci bir kişidir; eşi Çaas Han ona şöyle seslenir: "Genişleyen yerin üstünde / Benim bilmediğim şey yok dersin.” (Erdal Şahin, Hakas Destanı Altın Çüs, Türk Dünyası Araştırmaları Vakfı, İstanbul, 2007, s. 80) O, ölmüş kimseyi dirilten sırrı Altın Çüs'e söyler. Hıyan Han'ın kızı, Alıp Möke'nin ilk eşi Hıyan Arığ da destanın kadın kadrosunda yer alan bir diğer isimdir. Destan sahnesine ilk çıktığında turp burunlu, firça yüzlü, yumuk gözlü, sarkık dudaklı, pek aptal bir kız olarak tasvir edilmiştir. Sonrasında Hıyan Han'ın Alıp Hara Han'dan korktuğu için kızının şeklini değiştirdiği söylenir. Bu kız aslında altmış saç örgüsü arkasında, elli saç örgüsü omzunda, pek güzel, pek temiz bir kızdır. Bilici ve sezici özelliğe de sahiptir; ne zaman Alıp Möke'nin yurduna bir haber gelecek olsa onu uyku tutmaz, yatağında huzursuzca döner durur. Destanın kadın kadrosunda bu isimlerin dışında Altın Çüs'ün eşi Ah Çibek Arığ, Ah Han'ın kızı ve Kök Molat'ın eşi Ay Arı̆̆, Çaas Han'ın kızı ve Üzüm Han'ın eşi Ay Çarıh; düşman kadrodan Hara Han'ın ak gözlü, kızıl yüzlü kızı Hara Ninci ve Pora Han'ın kızı Pora Ninci (düşman kuzenler) de mevcuttur. Fakat onlar hakkında pek fazla bilgi verilmemiş, onların anlatımları uzun tasvirlerle desteklenmemiştir.

20 Türk destanlarında at motifi ile ilgili şimdiye kadar yapılan bütün çalışmalar kahramanın atının kahraman için bir yoldaş, kardeş, arkadaş, sırdaş, yardımcı, koruyucu vb. olduğundan; onun konuşma, uçma, engelleri aşma, zor yerleri geçme, yeraltına inip gökyüzüne çıkma, tehlikeleri sezme ve kahramanı bu tehlikelere karşı uyarma, şekil değiştirebilme, hava olaylarına müdahale edebilme vb. özelliklerinden bahseder. Kahramanla atının ayrı düşünülemeyeceği, kahramanın adının atının adı olmadan anılamayacağı ve atı olmadan bir kahramanın başarılı olabilmesinin mümkün olamayacağı bu çalışmalarda özellikle vurgulanır Altın Çüs destanında atın güçlülüğü, güvenilirliği, sadakati ve şefkati, alışılmışın dışında bir 
bırakmasını, çocuk er olur ise o çocuğun bütün halkın başına geçirilmesini söyler. Alıp Hara Han ile Alıp Han mücadele ederken Altın Arığ doğum yapar. Doğum başlamadan hemen önce ak kula at Altın Arığ'ın yanına gelerek yurdun parçalanacağını, bu nedenle doğacak çocuğun bir an önce ona verilmesi gerektiğini belirtir. Doğum olur olmaz da ak kula at ve onun ak sarı kulunu, çocuğu alarak yere mi girdikleri, göğe mi çıktıkları belli olmadan ortadan kayboluverir yani o kadar hızlı kaçarlar ki kimse onları göremez. Bu kaçış sırasında ak kula at, kız yiğit Alıp Han Hıs tarafından oklanarak öldürülür. Ölmeden önce ak kula at, Alıp Han'ın oğlunu ak sarı kuluna emanet eder ve onu bir er gibi yetiştirmesini söyler. Çocuğu alıp dörtnala koşmaya başlayan ak sarı kulunun ayağı, denizi geçerken bir şeye takılır ve o, denizin içine çekilmeye başlar. Bu sırada yeni doğmuş çocuğun "Altın Arığ annemin iki memesini emseydim keşke." dediği duyulur. Ak sarı kulun da düşman Alıp Hartığa tarafından öldürülür. Alıp Han'ın çocuğunu ele geçirmeyi başaran Alıp Hartığa, çocuğun iki kolunu ve iki bacağını keser. Çocuk da Alıp Hartığa'ya, kanını gölgeli gök dağdan aşağı akıtmasını, kanın ak dere olup akacağını; kan, kara yerin içine geçerse kuytu yerde birikip bir altın yapraklı sedir ağacı ${ }^{21}$ çıkarak büyüyeceğini ve ağacın başında at başı kadar güzel bir

örneği içerir: Destan kahramanı daha yeni doğmuş iken babasının atına emanet edilir ve ata, kahramanı düşmandan kaçırıp uzaklara götürmesi tembih edilir. Alıp Han'ın ak kula atı, bu çocuğu korumak için canından olur. Türk destanlarında kahramanların atları ile birlikte doğdukları söylenir ki bu destanda da ak kula at, bu çocuk ile aynı anda ak sarı kulunu dünyaya getirir. Ak kula at ölmeden önce kendisine emanet edilen bu çocuğu ak sarı kulunun korumasına bırakır. Alıp Möke'nin adı verilirken bu ak sarı kulunun artık Alıp Möke'nin ak sarı atı olacağı ifade edilir. Destanın ilerleyen bölümlerinde Hıyan Arığ da aynı şekilde bir erkek çocuk dünyaya getirir; onu, yurtlarına saldıran düşmanlardan koruması için kendisi de yeni doğmuş olan kara sarı kuluna emanet eder. Bu erkek çocuğun yani Üzüm Han'ın adı verilirken kara sarı kulunun, Üzüm Han'ın kara sarı atı olduğu belirtilir.

${ }^{21}$ Sedir ağacı, mitolojilerde kutsal kabul edilen ve yaşam döngüsünün yeniden başladığına işaret eden ağaçlardan biridir. $\mathrm{Bu}$ nedenle daha çok tarım tanrıları veya tanrıçalarıyla ilişkilendirilmiştir. Doğanın yeniden canlanmaya başladığı dönemlerde bereket için sedir ağacıyla ilgili birtakım pratikler yapılır. Bunlardan biri, Hindistan'ın kuzeybatı sınırında Gilgitli Ari kabileleri arasında yapılan pratiktir. Onlar için sedir ağacı kutsaldır. "Buğday ekiminin başlangıcında halk Raja'nın ambarından bir miktar buğday alır; buğday, kutsal sedir ağacının filizleriyle karıştırılan bir kabuk içine konur. Sedir odunlarıyla büyük bir şenlik ateşi yakılır ve ekilecek buğday dumanın üzerine tutulur. Geriye kalanı öğütülür ve büyük bir çörek yapılır. Aynı ateşte pişirilerek ırgatlara verilir. Burada niyetin kutsal sedir ağacı yoluyla tohumu bereketlendirmek olduğu açıktır. Bütün bu örneklerde ürünün genellikle de yetiştirilen bitkilerin büyümesini artırma gücü ağaçlara bağlanmaktadır. Buysa doğaya aykırı bir şey değildir. Çünkü ağaç, bitki dünyasının en büyük ve güçlü üyesidir, insansa tahıl yetiştirmeye başlamadan önce farkına varmıştır bunun. Dolayısıyla, daha zayıf ve kendisine göre daha yeni bitkiyi doğallıkla daha yaşlı ve daha güçlü olanın egemenliğine bırakır. ..." (James Frazer, Altın Dal I, Çev: M. H. Doğan, Payel Yayınları, İstanbul, 2004, s. 72-74) Altay Türklerinin sedir ağacını "Tanrı'ya dua edilecek yer" olarak kabul ettiği söylenir. Onun tüm insanlara ve orman 
guguk kuşunun ${ }^{22}$ öteceğini söyler. Hemen sonrasında Alıp Hartığa, çocuğu öldürür. Çocuğun dediği gibi kan, gölgeli gök dağdan aşağı ak dere olup akar,

hayvanlarına hayat verdiği; kozalakları olmasa ormanda yaşamın da olmayacağı düşünülür. Altay boylarından Çalkanların boy ağacıdır. Ayrıca Altay ve Şorlarda avcılar ava gittikleri zaman sedir ağacının merhametine ve koruyuculuğuna inandıkları için bu ağacın altında konaklar. Avcı, ağacın altına konaklayacağı yeri hazırlamadan önce ağaç ruhuna yanında bulunan yiyeceklerden ve içkiden sunar (Deniz Gezgin, Bitki Mitosları, Sel Yayınları, İstanbul, 2010, s. 167).

22 Guguk kuşu, mitolojilerde yeni bir dönemin başlangıcını temsil eder ve ilkbaharın habercisidir. Doğum-ölüm-yeniden doğum sürecinde ise ölüm ile yeniden doğum arasındaki aralığ 1 belirtirken yeniden doğumun da müjdeleyicisidir. Çingene mitolojisine göre ruh, ilk önce bir guguk kuşunun bedenine girer, bir sonraki aşamada ise bir çingenenin bedenine geçer. Bu sebeple İngiltere'deki çingeneler guguk kuşuna dokunmaz; bu kuşun, kendine beden arayan, ölmüş bir çingenenin ruhunu taşıdığına inanırlar (Deniz Gezgin, Hayvan Mitosları, Sel Yayınları, İstanbul, 2007, s. 95.). Altın Çüs destanında da guguk kuşu, Alıp Han'ın Alıp Hartığa tarafından öldürülmüş olan erkek çocuğunun ruhunu taşır ve onun kelimeleri ile öterek destan kahramanına kendini belli eder. Bu sayede destan kahramanı Altın Çüs de ona, kendi bedeninde yeniden canlanabilmesi, hayat bulabilmesi için yardım eder. Hakasların Altın Arığ destanında kahraman, alpların temiz canının, asil ruhunun bedenlerinde taşınmadığını belirttikten sonra kendisinin canının, kanatlı kuşun ve güçlü av hayvanlarının üç defa mola vererek ulaşabileceği, yeryüzünün zirvesi olan Ak Dağ'ın zirvesindeki altı ayrı zirveli altın kayada duran iki başlı, altın tüylü, at başı büyüklüğünde altın guguk kuşunda olduğunu söyler (Fatma Özkan, Altın Arığ Destanı, Bilig Yayınları, Ankara, 1997, s. 247-249, 273-275). Altaylıların Cañar destanında Cer Kindigi Enezi'nin (Yer Göbeğinin Anası'nın) yaşadığı yerde koyun başı büyüklüğünde bir guguk kuşunun ötüp durduğu söylenir. Aynı destanda Cer Kindigi Enezi’ye bağlı olan ve kahramana yardımcı unsur olarak görülen, Altay iyesi bir guguk kuşu mevcuttur ki muhtemelen bu iki guguk kuşu birdir. Kahraman bu kutsal guguk kuşuna "Kudayım" diye seslenir. Bu kuş, olacakları önceden bilip kahramana haber verir; ona evleneceği insanı söyler; savaş atını ve giysisini de yine bu kuş verir. Destanın ilerleyen bölümlerinde de bu kuşun, kutsal bitiği (suduru) kahramana getirdiği anlatılır. Maaday Kara destanı, Cemeten Tuu'nun eteklerindeki yurtta dokuz boğumlu kutsal kavak ağacının üstünde her şeyi bilip sezen iki guguk kuşu olduğu söylenerek başlar. Yine Altaylıların Ak Tayçı destanında guguk kuşuna rastlanır fakat burada guguk kuşu, şekil değiştirme örneği olarak yer almaktadır. Kahraman, yeraltına inip Erlik'in demir sarayına ulaştığında kendisini altın bir guguk kuşuna dönüştürüp bir kavağa oturur ve ötmeye başlar. Kahramanın ötüşüne Erlik ile onun yedi oğlu ve kızı dayanamaz ve onlar, yerin altlarına doğru kaçar. Şorların Kağan Kes destanında da yine bir şekil değiştirme örneği olarak kahramana yardımcı olan yaşlı bir kadının altın bir guguk kuşuna dönüştüğü belirtilmiştir (Yaprak Pelin Uluışı, Sibirya Sahası Türk Destanlarında Yeraltı Dünyası, Pegem Akademi Yayınları, Ankara, 2018, s.76, 85, 97, 99, 101, 152, 160-161, 166, 179, 217). Şorlar, guguk kuşu ile "ecdat anne" arasında bir ilişki kurar; "Anne arketipinin guguk kuşundaki yansıması üzerine Şor destancılık araştırmacısı A. İ. Çudoyakov bazı tespitlerde bulunmuştur. Buna göre Şor Türkçesinin arkaik katmanlarında anne anlamına gelen ene, içe kelimelerinden önce kookemay 'guguk kuşu' kelimesinin olduğunu ve bunun da 'annecik' anlamında kullanıldığını belirttikten sonra bunun bizleri ecdat anne anlamındaki guguk kuşu kavramına, totemine götürdüğünü ifade eder.” (Erhan Aktaş, Hakas Destan Geleneği ve Kahramanlar, Kömen Yayınları, Konya, 2016, s. 139; A. İ. Çudoyakov, Şor Destan İncelemeleri, TDK Yayınları, Çev: C. Turgunbayer, Ankara, 2007, s. 127-128). Jean Paul Roux ise guguk kuşu hakkında Türk kültüründeki olumsuzlama ile ilgili bir bilgi verir. Bir çalışmasında, Yakutlara 
kara yerin içine geçerek kuytu yerde birikir ve burada bir altın yaprakl1 sedir ağacı çıkar. Ağacın başında at başı kadar güzel bir guguk kuşu görülür ve bu guguk kuşu “Alıp Han'ın yapayalnız çocuğu, tek zürriyeti benim." diyerek ötüp durur.

Altın Çüs destanı Alıp Han'ın anlatımı ile başlayıp Altın Çüs'e, oradan Altın Çüs'ün yoldaşı Alıp Möke'ye ve oradan da Alıp Möke'nin oğlu Üzüm Han'a geçer. Destan bu üç kahramanın özelliklerinden de ayrı ayrı bahseder, onlar destanın sonuna kadar aynı anda hayattadır ve destan boyunca beraber anlatılır. Yani destan geneline bakıldığında bu destanın üç ana kahramanı var diyebilmek mümkündür. Hatta bu destanın Kadışev'den "Ah Oy Attı̆̆ Alıp Han” (Ak Kula Atlı Alıp Han) başlığı ile derlenmiş olması Alıp Han'ın da ana kahramanlara eklenmesi gerektiğini düşündürebilir. Muhtemelen, çok eski bir döneme ait olan bu destan her icra edilişinde şekil değiştirdiğinden yazıya geçirilinceye kadar dört farklı anlatı bir araya gelmiş, kahramanlar arası akrabalık bağı dört farklı anlatıyı tek bir anlatıda toplamış veya diğer kahramanlar, icralar sırasında ilgiyi yüksek tutmak için ana kahraman kadar coşkulu anlatıldığından onlar da zaman içerisinde birer ana kahramana dönüşmüş olabilir. Gülsüm Killi Yılmaz, Hakas destanlarının icrasında üç kuşak anlatımının gelenek olduğunu, Hakas destanlarında üçten fazla kuşağın bir arada anlatılmadığını belirttiği için ${ }^{23}$ destanın ana kahramanları olarak Altın Çüs'ü, Alıp Möke'yi ve Üzüm Han'ı almak, destandaki anlatıma göre daha uygundur.

T. G. Taçeyeva tarafından destana ismi verilen Altın Çüs'ün destan sahnesine ilk çıkışı, at başı kadar güzel guguk kuşunun ötüşünden hemen sonradır. Destanda ak çehreli, kara saçlı; börksüz ve eldivensiz; sarhoşluğu çok $^{24}$, türkü söyleye söyleye gelen bir yiğit anlatılmaya başlanır. Bu yiğit,

göre guguk kuşunun ölümün habercisi olduğunu ve uğursuzluk getirdiğini Zelenin ve Strahlenberg'den aktarır (Jean Paul Roux, Orta Asya'da Kutsal Bitkiler ve Hayvanlar, Kabalcı Yayınları, İstanbul, 2005, s. 80, 374).

${ }^{23}$ Gülsüm Killi Yılmaz, "Hakaslarda Destancılık Geleneği II: Biçim, İçerik, İcra”, Modern Türklük Araştırmaları Dergisi, 7/3, 2010, s. 162.

${ }^{24}$ Tanrı'nın yeryüzündeki tecellisi, parçası, elçisi olan destan kahramanı destanda geçirdiği erginlenme süreci boyunca birtakım zafiyetler gösterebilir; çünkü $o$, mükemmele henüz ulaşamamıştır. Erginlenme süreci denilen süreç, destan kahramanını mükemmele ulaştırmak için verilen sınavlar ile doludur ve bu sınavlar başarı ile tamamlandığında artık hata yapmaz, kusursuz bir destan kahramanı ile karşıllaşılır. Destan sahnesine sarhoş olarak çıkan Altın Çüs'ün içkiye inanılmaz bir zafiyeti vardır. Destanın ilerleyen kısımlarında da, örneğin kendisi, Çaas Han'ın yurdunda "aracın içeceği”" denilen içkiden bolca içerken görülür ya da destanda Puruhan Arığg'ın ona “İçici Altın Çüs” şeklinde hitap ettiği ve bu sırada Altın Çüs'ün yine aracın içeceğinden içtiği anlatılır. Altın Çüs de kendisinden bahsederken "içmek için doğmuş" veya "içici doğmuş" şeklinde ifadeler kullanır. Bir oturuşta altı gün boyunca içtiği söylenir. Fakat şunu da belirtmek gerekir ki, bazı destanlarda sarhoşluğu yüzünden ana kahramana veya 
guguk kuşunun ötüşünü duyup onu dinlemek için sedir ağacının orada durur ve kuşu dinledikçe o da dertlenir. Orada, kendisinin Ah Han'ın oğlu Altın Çüs olduğunu söyler. ${ }^{25}$ Atı da dokuz kulaç boylu, ak kar gibi ak kula attır. Destanın anlatımı sırasında kahramanın kendisini şöyle tanıttığı görülür: "Altıya ayrılan ak dağın altında, / Altı ayrı ak ırmağın kıyısında, / Ak kar gibi ak kula atlı / Altın Çüs adım sanım. / Ah Han babamdır, / Ah Öleñ Arı̆̆ annemdir; / Altımda küçüğüm yok, / Üstümde büyügüm yok, / Yapayalnız doğmuş / Altın Çüs'üm ben." ${ }^{26}$ Onun savaş giyimi olarak ak deri zırhından ve zırhının içine giydiği deri giyiminden bahsedilir; börkü ve eldiveni yoktur. Silahları, atıp vurur oku ve ay genişliğindeki kılıcıdır. Altın Çüs'ün ak kula atının da gümüsslü dizgini ve kertikli eyeri olduğu ifade edilmiştir. Olağanüstü özelliklere sahip olan bu aran çula at büyük rüzgâr gibi uğuldar, büyük akıntılı ırmak gibi gürülder. O koştuğu zaman yerin tozu gökyüzünü kaplar. Ay gidilir yeri gecelemeden, yıl gidilir yeri yedi gün geçmeden koşar. Ak ve 1ssız yazıları, dolanıp akan suları, karşı duran dağları gören göz daha kapanmadan, kapalı göz daha açılmadan aşmışlığı çoktur.

Destanın devamında Altın Çüs, Çaas Han adında bir hanın yurduna gelir ve altın yapraklı sedir ağacının başındaki guguk kuşunu, bu kuşun söylediklerini Çaas Han'a anlatır. Çaas Han'ın eşi Çarıh Tana, Alıp Han'ın

yardımcı kahraman kadrosuna zararı dokunan ve bu nedenle "zafiyet" olarak görülen içki bu destanda, destan kahramanının başına kötü bir şey gelmesine sebep olmaz; aksine, ne kadar içerse içsin Altın Çüs asla düşmanın oyununa gelmez, mücadele sırasında ona yenilmez ve karşı tarafla yapılan yarışları kaybetmez. Söz gelişi Üzüm Han ile Ay Çarıh'ın düğününde de çok içen Altın Çüs, düğünün sonrasında sarhoş bir şekilde türküler söylerken en güçlü han olduğunu ispat etmeye çalışan Üzüm Han ile yarışa girişir ve bu yarışı kazanır. Üzüm Han bu yarıştan sonra Altın Çüs'ün üstünlügünü kabul eder ve bir daha asla onun karşısında yer almaz. Gülsüm Killi Yılmaz, Altın Taycı ve Xulatay gibi Hakas destan kahramanlarının da içmeyi sevdiklerinden bahseder (Gülsüm Killi Yılmaz, "Hakaslarda Destancılık Geleneği II: Biçim, İçerik, İcra”, Modern Türklük Araştırmaları Dergisi, 7/3, 2010, s. 163). Dolayısıyla Hakas destanlarında içki kullanımının rastlanan bir durum olduğunu söylemek mümkündür.

${ }^{25}$ Güney Sibirya Türk destanlarında ad alma birkaç şekilde görülebilir: Kahramana aile, boyun büyüğ̈̈ veya ulu biri tarafindan ad verilmesi, kahramanın kendi kendisine ad koyması, kahramanın destan sahnesine hâlihazırda adı ile çıkması gibi (Erhan Aktaş, "Aile İçi İlişkiler Çerçevesinde Hakas Destan Kahramanları”, Türk Kültürü, 2016/2, 2016, s. 51). Bu destanda Altın Çüs'ün adını kimin koyduğu belli değildir; fakat Huban Arığ gibi Hakas destanlarında kahramanların kendi adlarını kendilerinin verdiği örneklere rastlandığı için bu destanda da Altın Çüs’ün kendine ad verdiği düşünülebilir. Eğer Altın Çüs kendi adını kendisi vermiş ise burada aktarılması gereken bir bilgi mevcuttur ki Erhan Aktaş, "Hakas Destan Kahramanları Üzerine Bazı Değerlendirmeler" isimli yazısında bu bilgiye şu şekilde yer vermiştir: "Bahaeddin Ögel, ad koyma töreni sırasında Oğuz Han'ın kendi adını kendisi koymasının bir Moğol âdeti olduğunun Ebulgazi Bahadır Han tarafından belirttiğine değinir” (Bahaeddin Ögel, Türk Mitolojisi, 1. Cilt, Türk Tarih Kurumu Yayınları, Ankara, 2003, s.159).

${ }^{26}$ Erdal Şahin, Hakas Destanı Altın Çüs, Türk Dünyası Araştırmaları Vakfı, İstanbul, 2007, s. 99. 
oğlunu diriltebilmesi için Altın Çüs'e bir sır verir. Ona, guguk kuşunu tutup aran çula atın kuyruğundan üç kök kıl ve Altın Çüs'ün başından da üç kök kı1 kopartıp guguk kuşunu bunlarla bağlayarak bunları Alıp Han'ın ölmüş çocuğunun bedeninin içine koymak ve insanı dirilten otu bulup onunla bu bedeni tedavi etmek suretiyle Alıp Han'ın oğlunu diriltebilmenin mümkün olduğunu söyler. ${ }^{27}$ Altın Çüs, Alıp Han'ın oğlunu diriltmek için sedir ağacının olduğu yere tekrar gider ama Huu İney adındaki kötü büyücü, kendisinden önce gelip guguk kuşunu kaçırmıştır. Bu sefer Altın Çüs, Huu İney'in peşine düşer. Huu İney, yer arkası kara dağda bir ak otağ içerisinde yedi kıza dönüşerek oturur. Kendisine "Puruhan Arığ" denilen kızlardan biri Altın Çüs'e aracın içkisi diye kara, sarı ve kızıl sarı kaplara koyduğu ateşten içkileri verir. Bu içkilerin konulduğu kaplardan âdeta alevler çıkar; içkileri içenin kömür olacağı bellidir ama Altın Çüs'e hiçbir şey olmaz. Sadece aşırı sarhoş olan Altın Çüs, olduğu yerde sızar kalır. Guguk kuşu, Puruhan Arığ'ın sarı, kurbağa derisi pantolonunun cebindedir. Altın Çüs sızmadan önce kara yerin ağırlığını, yüce göğün kirini büyü ile çekerek Huu İney'in iki elini ve iki bacağını, kapanıp yalvarma pozisyonu almış şekilde yere yapıştırır. Bu, Altın Çüs'ün sahip olduğu olağanüstü özelliklerden biri olan "sihir (büyü) yapma özelliği” ile ilgili destanda görülen ilk örnektir. Altın Çüs'ü sızdı̆̆ı yerde öldürmeye gelen Alıp Hartığa, Huu İney'in yere yapıştığını fark eder. Onu kurtarmaya davrandığında kendisi de Huu İney'e yapışır. Bu arada Altın Çüs, içkilerin etkisi ile sızar ve üç gün sonra uyanır. Huu İney'e yapışıp kalan Alıp Hartığa'yı kollarından ve bacaklarından tutup keser. "Yaşı küçük çocuğu / Eziyet vererek öldürmüştün Alıp Hartığa, / Ah Han çocuğu Altın Çüs seni / Eziyet vererek öldürecek.” diyerek ay genişliğindeki kılıcı ile Alıp Hartığa'yı orada öldürür. ${ }^{28}$ Huu İney'in cebinden de guguk kuşunu alır ve kendi cebine koyar; onun da iki kolunu ve iki bacağını dibinden keser ve onu da kılıcı ile vurup öldürür.

Ak ot ve kök ot başını alarak ilaç yapan Altın Çüs ilk önce, gölgeli gök dağda ölüp kalan ak sarı kulunu diriltir. Sonra da ak kula atın kuyruğundan ve kendi saçından üç kök k1l kopartıp güzel guguk kuşunu bağlayarak onu ve ilacı, ölmüş olan çocuğun vücuduna koyar. Bunun üzerine çocuk dirilir. Oğlanın öldürülmeden önce Alıp Hartığa tarafindan kesilmiş olan elleri ve ayakları da yerine gelir. Altın Çüs'ün sahip olduğu bu özellik, Güney Sibirya

\footnotetext{
27 “Ölüyü diriltme” ve "insanı dirilten ot” unsurları Altaylıların Katan Kökşin ile Katan Mergen ve Kökin Erkey destanlarında, Tuvaların Alday Buuçu destanında ve Hakasların Altın Arı̆̆, Huban Arığg, Ah Çibek Arı̆̆, Han Mirgen, Ay Huucın ve Altın Taycı gibi destanlarında da görülmektedir.

${ }_{28}$ Erdal Şahin, Hakas Destanı Altın Çüs, Türk Dünyası Araştırmaları Vakfı, İstanbul, 2007, s. 97. 
Türk destan kahramanlarının genellikle sahip olduğu ve Şamanizm etkisiyle anlatılara girdiği düşünülen "emçilik" özelliğidir. ${ }^{29}$

Altın Çüs ve Alıp Han'ın oğlu beraber Altın Çüs'ün yurduna varır. Burada Altın Çüs oğlana "Alıp Han babalısın, / Altın Arığ annelisin; / Altında küçüğün yok, / Üstünde büyüğün yok, / Ak sarı atlı Alıp Möke / Adın sanın olsun." diyerek ad verir. ${ }^{30}$ Destanda ilk ad verme motifi bu örnekte görülür. O zamana kadar giyimsiz dolaşan Alıp Möke deri ceket, ak deri pantolon, dokuz düğmeli ak deri zırh, ay şeklinde sadak ve ay biçimli börkten oluşan savaş giyimini Altın Çüs'ün otağında giyinir ve savaş gereçlerini de alarak Altın Çüs'ün yanına gider. Altın Çüs de onu, baba malını ve halkını kontrol etmesi için yurdunda dolaşmaya gönderir.

Altın Çüs ve Alıp Möke, Alıp Möke'nin babası Alıp Han'ın malını ve halkını kurtarmak için bu malı ve halkı alıp giden Alıp Hara Han ile mücadele etmeye karar verir. Büyük bir savaş olur. Bu savaş, diğer Hakas destanlarının savaş tasvirlerinde kullanılan cümlelere benzer cümlelerle anlatılır: "Açılmaz gibi ak duman sardı, / Yükselmez gibi gök duman yayıldı; / Yerin üstü kararıp tozlanır, / Gökyüzü kızarıp yanar. / Eyer kolanına döşenerek yüğrük at / Çok yıkılıp ölür, / Kollarına yaslanarak yiğitler pehlivanlar / Çok yıkılır, çok ölürler. / Onlar böyle savaşıp, / Eski ay batar, / Yeni ay çıkar, / Yiğidi tamam öldürdüler, / Pehlivanı tamam yıktılar; / At cesetleri ala dağ gibi oldu, / Er cesetleri sıradağ gibi oldu. / Ak duman açılır, / Gök duman kalkar, / ..." Destanın en heyecanlı ikili mücadeleleri, bu savaşın anlatımı sırasında Altın

\footnotetext{
${ }^{29}$ Mehmet Yılmaz, destanlardaki kahraman tipinin ilk örneklerinin "kahraman şaman tipleri” olduğunu ve en eski şamanların bir uzantısı olan bu kahramanların zamanla insan kahraman tipine dönüştüklerini C. M. Bowra'dan aktardığı bilgiler doğrultusunda Hakas destanı Huban Arığ'da kadın kahramanlar üzerine yazdığı makalesinde ifade etmiştir (Mehmet Yılmaz, "Hakas Kadın Kahramanlık Destanlarından Huban Arı̆̆g'da Kadın Kahramanlar", Journal of New World Sciences Academy (NWSA). 6/2, 2011, s. 242). Bu tip kahramanlar sihir (büyü) yapma, emçilik, hava olaylarına müdahale etme, bilici ve sezici olma, yeraltına inebilme, yardımcı veya koruyucu ruhlara, gizli bilgilere sahip olma vb. şaman özellikleri ile donatılmıştır. Altın Çüs destanında Altın Çüs'ün sahip olduğu olağanüstü özellikler dikkate alındığında onun "şaman" olduğunu söylemek aslında mümkün değildir; çünkü onda her ne kadar bilici, sezici, emci vb. özellikler olsa da bu, ilk şamanlara ait tüm özelliklerin onda bulunduğunu göstermez. Fakat aynı zamanda şunu da belirtmek gerekir ki Altın Çüs, şamanlara ait olan diğer özellikleri zamanla kaybetmiş olabilir, destan yazıya geçirilinceye kadar onun şamanlığına dair parçalar unutulmuş olabilir veya destan derlemesi sırasında destanın icracısı, Altın Çüs için diğer şaman unsurlarını vermeyi unutmuş olabilir. Dolayısıyla burada şöyle bir ifade kullanmak daha doğru olur: Hakas destanlarının ana kahramanlarına bakılarak Huban Arı̆̆ destanında Huban Arığ'ın tam bir şaman örneği olduğu söylenebilir ama Altın Çüs destanında Altın Çüs’ün birtakım şaman özelliklerine sahip olduğunu söylemek daha doğru olur.

${ }^{30}$ E. Şahin, age., s. 103.

Trakya Üniversitesi Edebiyat Fakültesi Dergisi, Cilt: 10 Sayl: 19, Ocak 2020, s. 169-192
} 
Çüs ile Alıp Hara Han ve Alıp Möke ile Çil Hara Hıs arasında geçer: "Alıp Hara Han, ay kara attan inip ilerleyip, / İki elini ovup, / İki eteğini sikarak geldi, / Altın Çüs'le karşı karşıya / Koşup gelip, çarpıştığında / Dağ dağa çarpmış gibi, / Sıradağ sıradağa çarpmış gibi, / Çil Hara Hıs'la Alıp Möke / Koşup gelip çarpıştı, / Bellerinden kapışıp yiğitler / Orada dövüşüp, orada tutuştular. / Kara yerin üstü kararıp rengi attı, / Yüce gökyüzü / Kızarıp yandı, / Açılmaz gibi ak duman sard1, / Yükselmez gibi gök duman yayıldı. / Otlarken mal otladığı ottan ayrılır, / Halk, türlü tebaa / Yediği, içtiği yemekten ayrılır, / Etrafa bakarlar; / Yiğitler dönseler, / Yerin zirvesi kara dağ, / Yerinde duramadan, / Sallanır gibi olur. / Dağ dağılır, / Irmak dalgalanır. / ... / Alıp Möke oturup düşüp, kalktı, / Kalkıp altı kez dönüp, yedi kez dolaşıp, / Çil Hara Hıs'ı attı. / Kara yere daha düşmeden, / Çil Hara Hıs / Kırk kıvılcım olarak / Saçılıp gitti. / . . / Altın Çüs Alıp Hara Han'ı / Çöküp yukarı kaldırdı; / Kara yerden kaptırmad1, / Süpürge otundan tutturmad1, / Yüce gökyüzüne kaldırdı. / Altı kez dönüp, yedi kez dolaşıp, / Kaldırıp bıraktı; / Dönmesine firsat vermedi, / Kara yere daha düşmeden tepti, / Beli üzerine tepti, / Omurgasını ezip bastı. / Alıp Hara Han, kızıp bağırarak, / Sızlanıp inleyerek ölüp gitti." ${ }^{31}$ Hakas kahramanlık destanlarında ana kahramanların mücadeleler sırasında düşmanı öldürme şekillerinin kaldırıp yere çalarak belini tepip omurgasını kırmak şeklinde olduğu anlatılır. ${ }^{32}$ Savaş meydanlarındaki diğer yiğitlerden de düşmanı bu ş̧ekilde öldürmeleri beklenir. Hatta bazı destanlarda bu şekilde bir son ile öldürülmeyen düşmanın neden "hakkıyla" öldürülmediği sorgulanır. Bu öldürme şekli, destanın ilerleyen bölümlerinde bir kez daha geçer: Altın Çüs, Mögi Hara Han adlı bir düşman ile ikili mücadeleye girişir. Tam bir destan kahramanına yakışır şekilde Mögi Hara Han'1 kaldırıp beli üzerine yere vurur, omurgasına basıp onu ezer ve düşmanı inleterek orada öldürür.

Bu savaş sonrasında Altın Çüs ve Alıp Möke, Alıp Hara Han'ın esir ettiği halkları kurtararak onun yurdunu parçalar. Alıp Möke, bu esir halklar içerisindeki kendi halkına şöyle seslenir: "Yerli kişi yerine dönsün, / Sulu kişi suyuna dönsün; / Kendi malınızı bölüp, / Kendi halkınızı bölüp, / Yerinize ulaşıp, / Nasıl yaşadıysanız siz, / Yine öyle yaşamaya başlayınız.” Hanlar ve

\footnotetext{
${ }^{31}$ E. Şahin, age., s. 107-111.

32 Örneğin Hakasların Ah Çibek Arığ destanında da destan kahramanı Ah Çibek Arı̆̆'ın düşmanı Ay Molat ile mücadelesi anlatılırken "Ay Molat'1 bir öne doğru bir tersine doğru yanlarına düşürdü. / Otura düşüp ayağa kalkıverdi. / [Bir şeye] tutunmasına, saldırmasına [olanak] vermedi, / Kan tengri bağrına [dek] kaldırıverdi. / Altı, yedi [defa] döndürüp / Kaldırıverdikten sonra firlattı. / Kara yere ulaştığında / Belini [birbirinden] ayıracak biçimde tepti, / Boynunun arka kısmını kırılacak biçimde tepti. / Acısını toplayıp, bağırıp / Ağırını toplayıp, çığlık atıp / Ay Molat oracıkta ölüverdi." şeklinde benzer bir anlatım söz konudur (Timur Davletov, Ah Çibek Arı̆̆, TÜRKSOY, Ankara, 2015, s.115).
} 
beyler de bu sözlerin üzerine Alıp Möke'ye şöyle dua eder: "Yok olmaz yerli olunuz, / Kesilmez soluklu olunuz." ${ }^{33}$ Parçalanan yurttan esir on iki han çıkar; bu hanlar, mallarını ve halklarını alıp kendi yurtlarına gider. Yurtta sadece Alıp Hara Han'ın halkı ve malı kalır. Bunun üzerine öksüzü görse içi acıyan, düşkünü görse kalbi sızlayan; öksüz kulunu at, öksüz oğlanı er yetiştiren yiğit Altın Çüs, Alıp Möke’ye şöyle der: "Ey Alıp Möke, yazı yerde mal kalmasın, / Issız yerde mal kalmasın, / Sacayağını yıkalım, bacayı devirelim; / Otlattığın malını, halkını / Memleketine sürüp git." ${ }^{\prime 4}$ Hakas destanlarında bu tip sahneler sırasında kahramanlar, kendi halklarına veya esir halkların tamamına, kendilerinde bulunan "liderlik" özelliğini ön plana çıkartacak şekilde seslenişlerde bulunur ve bu seslenişlerde genellikle kalıp ifadeler kullanır. Halklar da bunun karşılığında yine kalıp ifadeler ile bu hanlara dua edip minnetlerini sunar. Altın Çüs destanında kahramanın liderlik özelliğine sadece yukarıdaki iki örnekte vurgu yapılmaz. Destanın başında Altın Çüs'ün babası Alıp Han, halkına yaya yürümeyip atın iyisine binmelerini; giyimsiz, çıplak gezmeyip iyi giyinmelerini söyler. Halk da ona "Hanlık ederse hanımız Alıp Han, / Beylik ederse beyimiz Alıp Han." şeklinde şükranlarını sunar. ${ }^{35}$ Başka bir örnekte düşmanları Hara ve Pora Han'1 yenip onların yurdunda esir olan on iki hanı serbest bırakan Altın Çüs, bu hanlara şöyle seslenir: "Hara Han, Pora Han'ın yerinde / Bizim zaferimiz oldu. / Yurdunu yağmalatan on iki han / Sert yönetim altında şimdi sızlanmaz, / Yerli kişi yerine dönsün, / Sulu kişi suyuna dağılsın, / Kendi malını, kendi halkını / Tümünü ayırıp, şimdi döndün. / Nasıl yaşadıysanız siz, / Yine öyle yaşayınız, / Halkınızı tebaanızı / Aydınlık güne çıkarıp, / İyi hayat sürünüz." Onlar da bu sözlere karşı Altın Çüs için

\footnotetext{
${ }^{33}$ E. Sahin, age., s. 112.

${ }^{34}$ E. Şahin, age., s. 114.

${ }^{35}$ E. Şahin, age., s. 51.

Trakya Üniversitesi Edebiyat Fakültesi Dergisi, Cilt: 10 Sayl: 19, Ocak 2020, s. 169-192
} 
şöyle dua eder: "Ah Han çocuğu Altın Çüs, / Yok olmaz yurtlu ol, / Kesilmez soluklu ol." ${ }^{36} ;{ }^{37}$

Alıp Hara Han ile yapılan savaştan sonra Altın Çüs ve Alıp Möke, Alıp Han'ın halkı ve malı ile birlikte onun yurduna doğru ilerler. Yolda Alıp Han'ın cansız bedeni ile karşılaşırlar. Kahramanın emçilik özelliğini kullanarak ölüyü diriltmesi beklenirken Altın Çüs, bu bedeni diriltemez; çünkü her bedenin bir yeniden dirilme zamanı vardır. Alıp Han'ın cesedini inceleyen Altın Çüs, bu bedenin yeniden dirilme zamanının geçmiş olduğunu fark eder. Onun cesedini kaya ve taşlarla kapatarak obaya inerler. Bu sefer de Alıp Möke'nin annesi

${ }^{36}$ Burada bir meseleye daha temas etmek gerekmektedir. Altın Çüs destanında veya diğer Hakas destanlarında destan kahramanlarının her savaşta galip geldikleri ve düşmanın yurdunu ele geçirdikleri görülür; fakat bu yurtları, kendi yurtlarına dâhil ettiklerinden hiç bahsedilmez. Hatta onlar, bu yurtlardan ayrılmadan önce yurdun başına, halka adil davranabilecek ve halkı refah içerisinde yaşatabilecek, malların sayısını arttıracağına inandıkları hanlar bırakır. O zaman şu sorunun tartışılması icap eder: Hakas destanlarında kahraman dünya hâkimiyeti kurmaya mı yoksa dünya nizamını sağlamaya mı çalışır? Erhan Aktaş, Hakas destanlarında dünya hâkimiyeti kurma amacının söz konusu olmadığını belirtir. Kahramanlar Orta Dünya'ya mahsus yılkı hırsılı̆ğı, boy esareti vb. sorunları çözmek için çevre boylarla mücadele hâlindedir. Sınır ötesi tek mücadele, Moğol hanları ile olan mücadeledir; o da nadiren Hakas destanlarında yer alır (Erhan Aktaş, "Hakas Destan Kahramanları Üzerine Bazı Değerlendirmeler”, Çă̆daş Türkoloji Araştırmaları, Ank. Ünv. Basımevi, Ankara-Abakan, 2014, s. 201). Doğrudan bir bölge ya da dünya hâkimiyeti gibi bir amacı olmadığı için kahraman, düzenli bir orduya sahip değildir. Kahraman mücadeleleri, tek başına veya yoldaş1 ile birlikte verir (E. Aktaş, agm., s. 202). Mehmet Aça, Batı Türklerinin (Oğuzların) geniş bir coğrafyaya yayılarak çok daha erken dönemlerde büyük devletler kurabilecek seviyeye gelmeleri sebebiyle onlara ait destanlarda devlet kurma ve dünyaya nizam verme düşüncesinin çok gelişmiş olduğu; fakat Kuzey ve Güney Sibirya Türk gruplarının destanlarında kahramanların daha çok yurtlarını işgal eden komşu hanlarla mücadele edip daha bölgesel ve daha dar bir çerçevede, daha çok kendi aileleri ve kabileleri adına mücadele ettiği şeklinde benzer bir düşünceye sahiptir (Mehmet Aça, “'Köne Epos' (Arkaik Destanı) Kavramı ve Türk Halk Hikâyelerindeki ‘Âşıklara Mahsus Evlilik' Konusunun Kaynaklarından 'Alplara Mahsus Evlilik'”, Millî Folklor, 12 /47, 2000, s. 9-10). Bu iki düşünceye ek olarak şunları söylemek mümkündür: Sibirya sahası Türk destanlarında kahraman, yaşadıkları coğrafya tam olarak belirtilmeyen halkları özgürlüklerine, kendi halkını veya yardım için geldiği yurtların halklarını da yurtlarına kavuşturur. Bu bilinmeyen coğrafya, yeryüzünde veya yeraltında bir veya birden çok yer olabilir. Destan kahramanı, destan boyunca söz konusu coğrafyayı düzenlemek için mücadele verip durur, düşmanın esir alıp zulmettiği halkları özgürlüğüne kavuşturur ve mallarını da alarak kendi yurtlarına gitmeleri için onlara izin verir; yerli halka ise yurtlarında kalmalarını ve mallarına sahip çıkmalarını ögütler. Her ne kadar daha erken dönemlerde büyük devletler kurma ve tüm dünyaya hâkim olma anlayışı Sibirya sahası Türk destanlarında görülmese de buradaki durum, dünya nizamını sağlamaya çalışmaktır. "Kahramanın arkaik destanlardan orta dönem kahramanlık destanlarına kadar nihai hedefi, ortaya çıkan sahanın ve zamanın sınırları dâhilinde yeryüzüne düzen getirmektir." (Ülkü Kara Düzgün, "Türk Destanlarında Merkezi Kahraman Tipinin Tipolojisi”, Folklor / Edebiyat, C. 18, S. 70, 2012, s. 28)

${ }^{37}$ E. Şahin, age., s. 141. 
Altın Arığ'ın cansız bedenini görürler. Altın Çüs bu bedeni de inceler ve Altın Arı '̆'ın yeniden dirilme zamanının geçmediğini anlar. Onu hemen orada tedavi edip diriltir. Kahramanın emçilik özelliğini kullanarak kişiyi ya da herhangi bir canlıyı bitki veya özel bir eşya ile dirilttiği destanlara, Sibirya sahası Türk destanlarından Kan Ceeren Atlı Kan Altın, Er Samır, Ölöştöy, Kan Sulutay, Katan Kökşin ile Katan Mergen, Han Mirgen, Ah Çibek Arı̆̆, Alday Buuçu, Ton Aralçın, Boktu Kiriş Bora Şeeley, Han Şilgi Atlı Han Hülük, Tanaa Herel, Altın Tayçı, Er Sogotoh gibi destanlar örnek gösterilebilir. $^{38}$ Ayrıca kahramanın emçilik özelliğini kullanarak ölüyü diriltmeye çalışırken başarılı olamadığı yukarıdaki gibi örneklere de yine Sibirya sahası Türk destanlarında rastlamak mümkündür.

Türk destanlarında kahramanın yanında yer alan ve müşkül zamanlarında genellikle yardımına koşan, kahramanın kader birliği yaptığı, fiziksel özellikleri ve savaşçılığı bakımından kahramana benzeyen ama destanda her zaman kahramandan bir adım geride duran; kahramanın yoldaşı, sırdaşı, bilicisi, uyarıcısı, silah arkadaşı olan birinin olduğu görülür. Altın Çüs destanında bu kişi, ana kahramanlardan biri olan Alıp Möke'dir. Destanda onun doğum ve ad verme sahnesi vardır; savaş giyimini, gereçlerini ve atını nasıl aldığı anlatılmıştır. Alıp Möke, babasının malını ve halkını kurtarmak için mücadeleye girer, iki kez evlenir ve destan son bulmadan önce de yurdunu oğluna bırakır. Kısaca destanın sonuna kadar aktif olarak destan sahnesinde yer alır. Bu durumda destan, Altın Çüs'ten daha çok Alıp Möke'nin destanı gibidir; fakat kendisinin, Altın Çüs'ün yolunda, yanında, yardımında olduğu da destanın anlatımı sırasında dinleyiciye / okuyucuya hissettirilir. Destanın bir yerinde Altın Çüs şöyle der: "Üstüne bindiğim ak kula at, / İpek dizginini yayıp koşarak, / Bu yere koşup gelse, / Gider miydin, Alıp Möke? / Yüğrük ak kula at, / Eyer desenini, rengini silip, / Koşup gelse bu yere, / Yeter miydin, Alıp Möke?” Bunun üzerine Alıp Möke şöyle cevap verir: “Ölmüş bedenimiz bir dağ olur, / Akan kanımız bir dere olur, / Hiç birbirimizi bırakmayız, ağabey." ${ }^{39}$ Sonrasında Altın Çüs'e bir saldırı olur; Altın Çüs'ün atı da Alıp Möke'den yardım istemeye gelir. Alıp Möke'nin hanımı Hıyan Arığ, Altın Çüs'ün dayanamadığı düşmana Alıp Möke'nin hiç dayanamayacağını söyleyerek eşinin gitmemesini ister. Alıp Möke şöyle der: "Altın Çüs'ün öldüğü yerde ben de ölürüm, / Altın Çüs'ün yattığ1 yerde ben de yatarım."40 Eşine bu cevabı verdikten sonra da atına atlayıp hemen yola koyulur.

\footnotetext{
${ }^{38}$ Yaprak Pelin Uluışı, Sibirya Sahası Türk Destanlarında Yeraltı Dünyası, Pegem Akademi Yayınlar1, Ankara, 2018, s. 106-108.

${ }^{39}$ E. Şahin, age., s. 116.

${ }^{40}$ E. Şahin, age., s. 120.

Trakya Üniversitesi Edebiyat Fakültesi Dergisi, Cilt: 10 Sayl: 19, Ocak 2020, s. 169-192
} 
Bir gün donanımlı altı ordu Alıp Möke'nin yurduna gelir ve savaş ilan eder. Hara Han'ın kızı at kaldırmaz Çil Hara Hıs, ak sarı atlı Oh / Ot Han gibi yiğitler bu savaş için altı ordu ile birlikte hazır beklemektedir. Belli ki çok büyük ve kanlı bir savaş olacaktır. Bu sırada da Alıp Möke'nin eşi Hıyan Arı̆̆ doğum yapmak üzeredir. Altın Arığ'ın doğumu sırasında gerçekleşen at ile haberleşme ve atın yardımı ile ilgili bölümün benzeri, destanın bu kısmında da geçmektedir. Kara sarı kulun Hıyan Arığ'ın yanına gelerek doğacak çocuğu kendisine vermesini söyler. Hıyan Arığ doğum yaptıktan sonra oğlunu kuluna bindirir ve onunla gönderir. Sarp dağın üzerine vardıklarında bileği taşı karınlı, biz burunlu Huu İney onları fark eder ve boz kurda dönüşerek onların peşinden gider. Altın Çüs'ün oğulları ak boz atlı Ah Molat ve gök boz atlı Kök Molat da tam bu noktada destana dâhil olur. Ah Molat, kara sarı kulunu ve Alıp Möke'nin yeni doğmuş oğlunu alarak Altın Çüs'ün yurduna döner; Kök Molat ise Huu İney'in peşine düşer.

Altın Çüs'ün yurduna geldiklerinde Alıp Möke'nin yeni doğan çocuğuna Altın Çüs'ün eşi Ah Çibek Arığ, dokuz ağızlı ak taş sandığından -ki Altın Çüs'ün de savaş giyimi bu sandıkta durmaktadır- ${ }^{41}$ dokuz düğmeli canlı zırh çıkartır. Daha önce de Alıp Möke'nin savaş giyimini tedarik eden Altın Çüs ve Ah Çibek Arığ'ın şimdi de Alıp Möke'nin oğlu için savaş giyimi tedarik etmesi dikkat çekicidir. Dokuz düğmeli canlı zırh öyle bir zırhtır ki alev gibi yanar, ateş gibi sıcaktır; ona dayanabilen dayanır ama dayanamayan kara kömür olup yanar. Altın Çüs'ün soyundan kimse bu zırhı giyememiştir. Zırh kendisi giyilir ve düğmelenir. Alıp Möke'nin oğlu bu zırhı giyer, yanmaya başlar ama hemen sonra bu yanma geçer ve oğlan altın tahta oturup "Değerli adımı veriniz, / Şanlı ismimi söyleyiniz." der. Ah Molat yatak altından gümüş dizgini, kertikli eyeri ve silahları çıkartıp Alıp Möke'nin oğluna verir. O da gidip artık kulunluktan çıkmış olan kara sarı atı hazırlar. Sonrasında Ah Molat, "Alıp Möke babalısın, / Hıyan Arı̆̆ annelisin; / Altında küçüğün yok, / Üstünde büyügün yok, / Kara sarı atlı Üzüm Han / Adın sanın olsun.” diyerek destanın üçüncü ana kahramanına ad verir ${ }^{42}$. Bu, destanda geçen ikinci ad verme motifidir ve destana yeni girmiş, kendisinden hiç bahsedilmemiş bir

\footnotetext{
${ }^{41}$ Altay destanları Kan Sulutay, Katan Kökşin ile Katan Mergen, Cañar, Kökin Erkey, Erke Koo ve Ölöştöy, Tuva destanı Boktu Kiriş Bora Şeeley gibi destanlarda anlatılan ve genellikle kişilerin canlarının veya kutsal sudurların (bitiklerin) saklanması amacıyla kullanılan özel sandıklar, Hakas destanlarında yine özel oldukları belirtilerek şahsi eşyaların, özellikle de savaş ve at giyimleri ile silahların konulduğu sandıklar şeklinde verilmektedir. Altın Çüs destanındaki bu kullanıma ek olarak Huban Arığ destanında da kahramanın savaş giyimi ve kullanacağı gereçler, annesi Hıyan Arığ tarafından, zamanı geldiğinde kendisine verilmek üzere kara bir sandığa konularak saklanmıştır.

${ }^{42}$ E. Şahin, age., s. 131.
} 
oğul tarafından bu adın veriliyor olması, farklı bir örnek teşkil etmesi açısından önemlidir.

Üzüm Han, Altın Çüs'ün ailesine, babası Alıp Möke'nin yurdunda olan büyük savaştan bahseder ve yurdunu, halkını, malını kurtarmak için oraya gitmesi gerektiğini söyler. Ah Molat ile birlikte Alıp Möke'nin yurduna doğru yola çıkarlar. Altın Çüs için Alıp Möke ne ise Üzüm Han için de Ah Molat o olur. O artık destanın sonuna kadar Üzüm Han'ın yardımcısı, yoldaşı, silah arkadaşıdır. Babasının yurduna vardıklarında Alıp Möke'nin Oh / Ot Han ile, Altın Çüs'ün de Çil Hara Hıs ile mücadele ettiğini görürler. Bunun üzerine savaşa katılan iki yiğit, düşmanları öldürerek bu savaşa bir son verir.

Bu büyük savaştan sonra Altın Çüs, Alıp Möke, Ah Molat ve Üzüm Han yerin aşağı yerinde, zirvesi taşlı dağın altında akan kara ırmağın, boz nehrin birlikte aktığı yerde yaşayan Pora Han ile Hara Han'a savaş açar. Yerin üstü kararıp tozlanır, gökyüzü kızarıp yanar; yine çok büyük bir savaş olur. Savaş sırasında Ah Molat, kardeşi Kök Molat'1 düşman Hara Han'ın kızı Hara Ninci'nin ve Pora Han'ın kızı Pora Ninci'nin elinden kurtarır ve hemen Ah Han'ın kızı Ay Arı̆̆ ile evlenip kendi yurtlarına gitmesini söyler.

Bu savaştan sonra Üzüm Han, Alıp Han dedesinin intikamını almak için Alıp Han Hıs'a savaş açar ve onu yener. Alıp Han Hıs'ı esir edip babası Alıp Möke'ye teslim eder ve bu sefer de parlak tüylü gök boz atlı Çaas Han ile mücadele etmek için Ah Molat ile birlikte Çaas Han'ın üzerine yürümeye karar verir. Çaas Han aslında düşman bir han değildir; zamanında kendisinin ve eşinin Altın Çüs'e yardımı dokunduğu destanda anlatılmıştır. Fakat Üzüm Han, delikanlılığının verdiği toyluk ile çevre hanların tamamından üstün olduğunu düşünerek sürekli bir yerlere saldırma hâlindedir. Üzüm Han'ın Çaas Han ile mücadele etmek istediğini duyan Altın Çüs bu duruma engel olmak için Alıp Möke ile birlikte Çaas Han'ın yurduna gider. Altın Çüs burada Çaas Han'ın kızı Ay Çarıh'ı Üzüm Han'a ister ve büyük bir düğün tertiplenmesini sağlar.

Altın Çüs ile Üzüm Han ne zaman karşılaşsa Üzüm Han, Altın Çüs'e selam vermez; üstelik ona ayı gibi şiddetle, kurt gibi dik dik bakar ve şöyle der: "Yüce Altın Çüs, / Geniş yerin üstünde / Beş yüğrük at koşmasın, / Bir yüğrük at koşsun; / Beş ulu yiğit olmasın, / Bir yiğit olsun." ${ }^{43}$ Bu sözlerden Altın Çüs, bir gün Üzüm Han'ın tek ve en güçlü olmak için kendisini öldürmek istediğini anlar. Hara Han, Pora Han, Alıp Han Hıs ve Çaas Han beş ulu yiğidin dördüdür; bu durumda sıra beşinciye yani Altın Çüs'e gelmiştir. Ana kahramanlardan birinin, destana ismini vermiş olan diğer bir ana kahramana

\footnotetext{
${ }^{43}$ E. Şahin, age., s. 140. 
karşı böyle kötü niyetli olması destanlarda çok da karşılaşılan bir durum değildir. Fakat bu durum, Üzüm Han'ın kötü niyetli olmasından çok, erginlenme sürecinde olması ile ilgilidir. Erginlenme sürecinde olan kahraman hatalarından kurtulup bireysellikten uzaklaşmak için bir dizi sınavdan geçer. Süreci tamamladığında mükemmelliğe erişecektir. Üzüm Han doğumundan hemen sonra dile gelip kendine ad isteyen, canlı zırhı yana yana giyip taşımayı becerebilen, atına sahip olur olmaz malını ve halkını kurtarmak için bu ata atlayarak dörtnala babasının yurduna gidip hiç durmadan savaş meydanına dalan bir cengâverdir ama aynı zamanda çok genç ve fevri bir kahramandır. Kendi düğününden hemen sonra çok sarhoş olan Altın Çüs ile kavga çıkartıp onu kışkırtmaya çalışır; amacı, bir an önce kendisinin Altın Çüs'ten üstün olduğunu kanıtlayabilmektir. Sonunda Altın Çüs'ü bir yarış için kışkırtmayı başarır; ikisi at koşturmaya karar verir. Birden çok kez at koşturduktan sonra, Altın Çüs'ün her defasında fazlasıyla üstün gelmesi üzerine Üzüm Han, onun en güçlü olduğunu kabul eder ve geri çekilip yurduna döner. Bu aldığı ders, onun erginlenme sürecini tamamlaması yolunda önemli bir basamaktır. Destanın geri kalan kısmında onun fevri davranışlarından bir daha bahsedilmez. ${ }^{44}$

Hakas destanlarında bitiş kalıpları birbirine ve diğer Türk destanlarının bitiş kalıplarına benzemektedir. Bazı destanlarda kahraman; ailesi, yakınları, malı ve halkı için verdiği onlarca mücadeleden sonra yurduna döner, savaş giyimini ve silahlarını çıkartır, atını doğaya salar, hanlığını oğluna veya kızına, bir akrabasına veya yakınına bırakır ve huzur içinde yurdunda oturmaya başlar. Üstünlüğünü çevre boylara ispatladığı için bir daha cesaret edip de yurduna saldıran olmaz. Bir başka bitiş kalıbında kahraman zafer, evlilik veya ölüm toyu tertiplenmesini ister ve destan bu toyun anlatımı ile biter. Bazı bitiş kalıplarında ise destan anlatıcısı, anlattıklarının gerçek

${ }^{44}$ Erhan Aktaş, Rasim Adasal'ın Yeryüzü Tanrllarl, Liderler, Komutanlar ve Kahramanlar Psikolojisi adlı eserinde aktardığı G. Lebon'un toplum psikolojisi hakkındaki dokuz maddesinden "heyecan baskısı" maddesine bir çalışmasında yer vererek belirli ve amaçlı bir toplum içerisindeki kişilerin, süreli heyecanların baskısı altında bulunduğunu söyler. Bu kişiler o an için mantıklı düşünme imkânı bulamaz ve duyguları ile hareket ederler (Erhan Aktaş, "Hakas Destan Kahramanları Üzerine Bazı Değerlendirmeler", Çağdaş Türkoloji Araştırmaları, Ank. Ünv. Basımevi, Ankara-Abakan, 2014, s. 199; Rasim Adasal, Yeryüzü Tanrları, Liderler, Komutanlar ve Kahramanlar Psikolojisi, Minnetoğlu Yayınları, İstanbul, 1979, s. 31-32). Destan kahramanları da bu kişilere örnektir ve onlar, erginlenme süreçlerini tamamlamadan önce hiddetli, aşırı, bencil, yanlış hareketlerde bulunan, hata yapmaya meyilli tiplerdir. Destan sonunda Üzüm Han toyluğunu atmış, bencilliğini yenmiş, heyecanını bastırabilmiş bir şekilde karşımıza çıkar. O artık kusursuz bir savaşçı ve tam bir liderdir. Babasının yerine yurdun başına geçtiğinde diğer destan kahramanları gibi atsız kişiyi ata bindirir, giyimsiz kişiye giyim giydirir. Yurdunda barışı sağlamak ve yurdunun malını arttırmak için uğraşan, adaletli bir han olur. 
olduğunu, bu anlattıkları yaşanırken kendisinin o yerde bulunduğunu, bu destanı anlatmaya da o yerden kalkıp geldiğini söyleyerek destana doğrudan dâhil olur ve birkaç düşüncesini daha belirtip destanı bitirir. ${ }^{45}$ Altın Çüs destanında bu saydığımız kalıpların ilki söz konusudur. Destanın sonunda Alıp Möke'nin yurdunun başına Üzüm Han geçer. Artık malı ve halkı o idare edecektir. Alıp Möke ise ak sarı atının eyerini çözüp onu ak yazıya salar, ay genişliğindeki kılıcını yüklüğe kaldırır ve dokuz düğmeli ak deri zırhını çıkartıp dokuz ağızlı sandığa koyar. Yurdunda, eşleri ile birlikte, mutlu bir şekilde yaşamaya başlar. Altın Çüs de yenilmezliğini çevre hanlara kanıtlamış olduğundan bir daha yurduna düşman uğramadan huzur içinde yaşar.

Altın Çüs destanında kahramanların özelliklerinin incelendiği bu makalede son olarak "şekil değiştirme"nin destandaki yerinden bahsetmek gerekir. Sibirya Türk destanlarında kahramanların en temel özelliklerinden biri şekil değiştirmedir. Kahramanın zor durumlardan kurtulabilmek, düşmandan kaçabilmek, geçilmesi gereken geçitleri aşabilmek, kendini belli etmeden yakınlarından haber alabilmek, düşmanın niyetini gizlice öğrenebilmek vb. sebeplerle şekil değiştirmesi gerekebilir. Kahraman sadece kendi şeklini değil, canlı varlıkların ve nesnelerin şeklini de değiştirebilir ve sadece ana kahraman değil, destanda yer alan ve olağanüstü özelliklere sahip olan diğer yardımc1 kahramanlar ve varlıklar ile kötü tarafa mensup olan kadro da şekil değiştirme özelliğine sahiptir. Destandaki ilk şekil değiştirme örneği şöyledir: Düşman Huu İney, bir ala yılan şeklinde denizin içinden çıkar ve ak sarı kulunu ayağından tutup onun kaçmasına engel olur. Sonra kendi şekline dönüşerek Alıp Hartığa'nın, ak sarı kulunu ve Alıp Han'ın oğlunu öldürmesini bekler. Alıp Hartığa bu ölümleri gerçekleştirdikten sonra Huu İney, altı kanatlı ala yılana dönüşerek uçup gider. Ardından o, yer arkası kara dağın ortasındaki ak otağda, biri "Puruhan Arığ" adı ile bilinen ve altın yakalı giyim giyen, altmış saç örgüsü arkasında, elli saç örgüsü omuzlarında yayılan yedi kız şeklini alır. Alıp Hara Han'ın oğlu Alıp Hartığa, yuvarlak başlı yüce kara ırmak olup akar. Başka bir örnekte Hıyan Han, Alıp Hara Han'dan korktuğu için kızı Hıyan Arığ'ın şeklini değiştirerek onu turp burunlu, fırça yüzlü, yumuk gözlü, sarkık dudaklı, pek aptal bir kız yapar. Destanda geçen diğer şekil değiştirme örnekleri şunlardır: Hıyan Arı̆̆ doğum yaptıktan sonra oğlunu kara sarı kuluna teslim eder; o da oğlanı alıp sarp dağın üzerine çıkarır. Bileği taşı karınlı, biz burunlu Huu İney onları görür ve silkinerek boz kurda dönüşüp kara sarı kulun ile Alıp Möke'nin oğlunu takip eder. Altın Çüs'ün oğlu Ah Molat, düşmanları Pora ve Hara Han kardeşlerin yurdundaki dokuz köşeli kara

45 Erhan Aktaş, “Hakas Türk Destanlarında Başlangıç ve Bitiş Kalıpları”, Prof. Dr. Fikret Türkmen Kitabı, Ege Ünv. Türk Dünyası Araştırmaları Enstitüsü, İzmir, 2012, s. 650. 
taş eve girmek için silkinerek Huu İney'e dönüşür. Ayrıca o, atını da teper ve at da ak erkeç sakalı olup oturur. Destanın bir başka yerinde ise Ah Molat, kötü büyücü Huu İney’i yakalamak için büyük bir kurgan yerine gizlenir. Orada atını teperek onu üç yıllık boz tezeğe dönüştürür. Kendi de silkinip büyük kurganın üzerinde karışık olarak büyümüş ot şeklini alır. Bu ot, oradan geçen Huu İney’i ayaklarından tutar ve bırakmaz.

\section{Sonuç}

Hakas Türklerine ait Altın Çüs destanı, diğer Hakas kahramanlık destanlarına nazaran kısa tasvirlere sahip olan ve heyecan unsuru yüksek tutulmak istense de aşırı dinamik olmadığı söylenebilecek bir destandır. Hakas destanlarında kahramanın fiziksel özellikleri, atının özellikleri ve kendisinin atı ile münasebeti, atını sürüşü, savaşa hazırlığı, savaş sırasında kullandığı güç ve savaş sahneleri, iyi ve kötü destan kadrosunun fiziksel vd. özellikleri ayrıntılı ve daha doyurucu tasvirlerle verilirken Altın Çüs destanında bu tasvirler nispeten daha zayıftır. Ana kahramanlar destan boyunca mücadele hâlindedir, bu mücadeleler dinamizmi sağlar ama yerin ve gögün inlediği, toza dumana karıştığı; bu nedenle gece mi gündüz mü olduğu savaş süresince belli olmayan, soluk kesici savaş sahneleri kısa kısa anlatılmıştır ya da ölen kahramanlar, son nefesini veren yiğitler, bu yiğitler için endişelenen analar veya eşler gibi dramatik sahneler, Altın Çüs destanında yoktur.

Hakas alıptı̆̆ nımahlarının mitolojik ögeler bakımından oldukça zengin olduğu ve Şamanizm'in izlerini fazlasıyla taşıdığı, üzerinde çalışma yapılan destanlarda açıkça görülmekte iken Altın Çüs destanında -örneğin Huban Arı̆̆ veya Ah Çibek Arı̆̆ destanına oranla- bu ögelerin ve izlerin azaldığ fark edilir. Kahramanın zafere ulaşmasını sağlayacak olan olağanüstü özellikleri, sihirli nesneleri ve yardımcı varlıkları destanda geniş bir yer tutmamaktadır. Altın tüylü köpek, ala boğa, yaşlı adam, şaman vb. olağanüstü varlıklardan yardım alma; hosto, bitik, örtü vb. sihirli nesnelere sahip olma, yeraltına inme veya gökyüzüne çıkma, şekil değiştirme, hava olaylarına müdahale etme, ölüyü diriltme ve hastayı sağaltma, sihir (büyü) yapma, bilici ve sezici olma gibi mitoloji ve Şamanizm kökenli olağanüstü özelliklerin bir kısmının destanda anlatılmış olması, destanı diğer Hakas destanlarından daha geç bir döneme tarihlendirebilir. Bu destan, diğer alıptığ nımahlar kadar eski de olabilir fakat yazıya geçirilene kadar bu olağanüstülüklerin bir kısmının unutulma veya destan anlatıcisindan derlenirken anlatıcının bu bir kisım özelliği atlamış olma ihtimali mevcuttur.

Destan aslında Alıp Möke'nin babası Alıp Han'ın yurdunda başlar. Çocuksuzluktan muzdarip olan Alıp Han'dır. Alıp Han geç yaşında bir çocuk 
sahibi olur ama o, çocuğunu hiç göremez. Bu çocuk, Alıp Möke'dir. Alıp Möke olağanüstü bir şekilde doğar; adını, atını, savaş giyimini ve gereçlerini destan sahnesine çıktıktan sonra alır; babasının malını ve halkını kurtarmak için savaşır ve düşmanla mücadelelere girer; iki kez evlenir; destan son bulmadan önce de yurdunu oğluna bırakır. Bir destan sırasında kahraman ile ilgili verilmesi gereken unsurlar, Alıp Möke'nin kendisinde verilmiştir; fakat destan "Altın Çüs" adını almaktadır. Altın Çüs ise destan sahnesine çıktığında adını, atını almış; yer yurt sahibi ve çevre hanlar tarafından tanınan; evli ve iki oğul sahibi bir destan kahramanıdır. Alıp Möke'yi diriltmesinden başlanarak onun olağanüstü özellikleri destanda ayrı ayrı örneklerle sıralanır. Üstünlüğünü herkese kanıtlamış, yenilmez bir kahraman olarak destanı tamamlar. Bir de Alıp Möke'nin oğlu Üzüm Han vardır ki onun da doğumu, adını alışı, fiziksel özellikleri, atı ve silahları, savaşçılığı ve mücadeleleri destanda anlatılmıştır. Destan sonunda Alıp Möke, yurdunu ona emanet eder. Bu bakımdan Üzüm Han, destanın üçüncü kuşağını temsil eden kahramandır. Onun destana ismini vermesi gerektiği düşünülmese de Alıp Möke'nin anlatıldığı ayrı bir anlatı ile Altın Çüs'ün anlatıldığ1 ayrı bir anlatı, zaman içerisinde Altın Çüs destanının çatısı altında birleşmiş gibidir. Hatta bu destan ilk olarak Kadışev’den “Ah Oy Attığ Alıp Han” (Ak Kula Atlı Alıp Han) şeklinde derlenip yayımlandığı için bir de Alıp Han'ın anlatıldığg ayrı bir anlatının olduğu ve destan yazıya geçirilinceye kadar o anlatının da Altın Çüs destanı ile birleştiği düşünülebilir.

\section{KAYNAKC A}

Aça, Mehmet, “'Köne Epos' (Arkaik Destanı) Kavramı ve Türk Halk Hikâyelerindeki 'Âşıklara Mahsus Evlilik' Konusunun Kaynaklarından 'Alplara Mahsus Evlilik’”, Millî Folklor, 12/47, 2000, s. 11-21.

Adasal, Rasim, Yeryüzü Tanrllarl, Liderler, Komutanlar ve Kahramanlar Psikolojisi, Minnetoğlu Yayınları, İstanbul, 1979.

Aktaş, Erhan, "Hakas Türk Destanlarında Başlangıç ve Bitiş Kalıpları", Prof. Dr. Fikret Türkmen Kitabl, Ege Ünv. Türk Dünyası Araştırmaları Enstitüsü, İzmir, 2012, s. 639-652.

Aktaş, Erhan, "Hakas Destan Kahramanları Üzerine Bazı Değerlendirmeler”, Çağdaş Türkoloji Araştırmalarl, Ank. Ünv. Basımevi, Ankara-Abakan, 2014, s. 191-215.

Aktaş, Erhan, "Aile İçi İlişkiler Çerçevesinde Hakas Destan Kahramanları", Türk Kültürü, 2016/2, 2016, s. 47-58.

Aktaş, Erhan, Hakas Destan Geleneği ve Kahramanlar, Kömen Yayınları, Konya, 2016.

Çobanoğlu, Özkul, Türk Dünyası Epik Destan Geleneği, Akçağ Yayınları, Ankara, 2003.

Çudoyakov, A. İ. Şor Destan Incelemeleri, TDK Yayınları, Çev: C. Turgunbayer, Ankara, 2007. 
Davletov, Timur, Hakas Kartalı Han Mirgen, Yurt Kitap-Yayın, Ankara 2005.

Davletov, Timur, Huban Arı̆̆. Hakas Türklerinin Kadın Yiğitlik Destanı, TÜRKSOY Yayınları, Ankara, 2006.

Davletov, Timur, Ah Çibek Arı̆̆, TÜRKSOY Yayınları, Ankara, 2015.

Davletov, Timur, “Türk Halklarının Köroğlu ve Ah Çibek Arığ Destanlarında Kadının Toplumsal Yeri”, Türk Tarihinde İz Bırakan Bolulular Çalıştayı Bildiriler, Kaan Matbaa, İstanbul, 2015, s. 217-226.

Davletov, Timur, "Türk Halklarının Dede Korkut Kitabı ve Ah Çibek Arığ Destanında Kadının Toplumsal Yeri”, III. Uluslararası Türk Dünyası Kültür Kongresi: Dede Korkut ve Türk Dünyası, Ege Üniversitesi Türk Dünyası Araştırma Enstitüsü, İzmir, 2016, s. 1661-1671.

Ergun, Pervin, Hakas Destancılık Geleneği ve Ay Huucın, Kömen Yayınları, Konya, 2010.

Frazer, James, Altın Dal I, Çev: M. H. Doğan, Payel Yayınları, İstanbul, 2004.

Gezgin, Deniz, Hayvan Mitosları, Sel Yayınları, İstanbul, 2007.

Gezgin, Deniz, Bitki Mitoslarl, Sel Yayınları, İstanbul, 2010.

Gürsoy Naskali, Emine, "Destanın Tarifi", Türk Dili Araştırmaları Yıllı̆̆g-Belleten 1992, Ank. Ünv. Basımevi, Ankara, 1995, s. 1-8.

Kara Düzgün, Ülkü, “Türk Destanlarında Merkezi Kahraman Tipinin Tipolojisi”, Folklor / Edebiyat, 18/70, 2012, s. 28.

Kara, Mehmet, Hakas Destanı Altın Taycı, Harf Yayınları, Ankara, 2013.

Killi Yılmaz, Gülsüm, "Hakaslarda Destancılık Geleneği II: Biçim, İçerik, İcra", Modern Türklük Araştırmaları Dergisi, 7/3, 2010, s. 154-178.

Ögel, Bahaeddin, Türk Mitolojisi, 1. Cilt, Türk Tarih Kurumu Yayınları, Ankara, 2003.

Özkan, Fatma, Altın Arı̆̆ Destanı, Bilig Yayınları, Ankara, 1997.

Roux, Jean Paul, Orta Asya'da Kutsal Bitkiler ve Hayvanlar, Kabalcı Yayınları, İstanbul, 2005.

Şahin, Erdal, Hakas Destanı Altın Çüs, Türk Dünyası Araştırmaları Vakfı, İstanbul, 2007.

Uluışık, Yaprak Pelin, Sibirya Sahası Türk Destanlarında Yeraltı Dünyası, Pegem Akademi Yayınları, Ankara, 2018.

Yıldız, Naciye, "Türk Destanlarında 'Çocuksuzluk", Millî Folklor, 21/82, 2009, s. 76-88.

Yılmaz, Mehmet, "Hakas Kadın Kahramanlık Destanlarından Huban Arığ'da Kadın Kahramanlar", Journal of New World Sciences Academy (NWSA), 6/2, 2011, s. 234-250.

Yolcu, Mehmet Ali, Türk Kültüründe Evliliğe Bağlı Kaçınmalar, Kömen Yayınları, Konya, 2014. 